\title{
Carbon, Nitrogen Dynamics and Soil Organic Carbon Retention Potential after 18 Years by Different Land Uses and Nitrogen Management in RWCS under Typic Ustochrept Soil
}

\author{
R.K. Naresh ${ }^{1}$, R.K. Gupta ${ }^{2}$, Vivek ${ }^{1}$, R.S. Rathore $^{3}$, S.P. Singh ${ }^{4}$, \\ Ashok Kumar ${ }^{4}$, Sunil Kumar ${ }^{5}$, D.K. Sachan', S.S. Tomar ${ }^{7}$, \\ N.C. Mahajan ${ }^{8}$, Lali Jat ${ }^{1}$ and Mayank Chaudhary ${ }^{*}$
}

${ }^{1}$ Department of Agronomy, Sardar Vallabhbhai Patel University of Agriculture \& Technology, Meerut-250110, U.P., India

${ }^{2}$ Borlaug Institute for South Asia (BISA), New Delhi-110 012, India

${ }^{3}$ Uttar Pradesh Council of Agricultural Research (UPCAR), Lucknow, U.P., India

${ }^{4}$ Department of Soil Science, Sardar Vallabhbhai Patel University of Agriculture \&

Technology, Meerut-250110, U.P., India

${ }^{5}$ Indian Institute of Farming System Research, Modipuram, Meerut-250110, U.P., India

${ }^{6}$ K.V.K. Ghaziabad; Department of Genetics \& Plant Breeding, Sardar Vallabhbhai Patel

University of Agriculture \& Technology, Meerut-250110, U.P., India

${ }^{7}$ RVSKVV, ZARS-A, B. Road, Morena -476001, (M.P.), India

${ }^{8}$ Institute of Agricultural Science, Department of Agronomy, Banaras Hindu University,

Varansi-221005, U.P., India

*Corresponding author

\section{A B S T R A C T}

A long-term field experiment was conducted to design and implement alternative production systems with increased resource use efficiency, productivity and to determine the effect of tillage systems and mineral fertilizers on soil organic

\section{Keywords}

Soil organic carbon, Conservation tillage, Crop residue management, Carbon, Nitrogen Dynamics

Article Info

Accepted: 24 September 2018 Available Online: 10 December 2018 carbon patterns. This experiment intended to evaluate the effects of these management strategies on soil structural formation and structural stabilization of a sandy loam soil. The shift from puddled - transplanted rice on the flat land to raised bed systems affects the productivity and resource use efficiency of the rice-wheat system. Therefore, the potential benefits and constraints of tillage crop residue practices need to be quantified on short to long-term basis, optimum layouts and management systems to maximize yield and efficiency. Due to lesser energy input and higher output $\mathrm{T}_{3} \mathrm{ZT}$ with 6 tha $^{-1}$ residue retained had $20 \%$ and $5 \%$ higher energy use efficiency than $\mathrm{T}_{7} \mathrm{CT}$ and $\mathrm{T}_{6} \mathrm{PRB}_{\text {with }} 6$ tha $^{-1}$ residue retained. Undisturbed soil samples were collected from the 15 to $100 \mathrm{~cm}$ soil layer in the field grown with wheat to assess SOC, bulk density, $\mathrm{C}$ restoration rate, $\mathrm{C}$ sequestered, $\mathrm{C}$ sequestration efficiency $(\%)$ and crop yield. However, at the end of the 18 years period, $\mathrm{SOC}$ was $25 \%$ greater with $\mathrm{T}_{6}$ than $\mathrm{T}_{7}, 16 \%$ greater with $\mathrm{T}_{4}$ than $\mathrm{T}_{1}$, and $17 \%$ higher with $\mathrm{T}_{2}$ than $\mathrm{T}_{7}$. Average SOC concentration of the control treatment was $0.54 \%$, which increased to $0.65 \%$ in the RDF treatment and $0.82 \%$ in the RDF+FYM treatment and increased enzyme activities, which potentially influence soil nutrients dynamics under field condition. Compared to $\mathrm{F}_{1}$ control treatment the RDF+FYM treatment sequestered 0.28 $\mathrm{Mg} \mathrm{C} \mathrm{ha}^{-1} \mathrm{yr}^{-1}$ whereas the NPK treatment sequestered $0.13 \mathrm{Mg} \mathrm{C} \mathrm{ha}^{-1} \mathrm{yr}^{-1}$. As tillage intensity increased there was a redistribution of SOC in the profile, but it occurred only between ZT and PRB since under CT, SOC stock decreased even below the plow layer. Increased SOC stock in the surface $50 \mathrm{~kg} \mathrm{~m}^{-2}$ under ZT and PRB was compensated by greater SOC stocks in the $50-200$ and $200-400 \mathrm{~kg} \mathrm{~m}^{-2}$ interval under residue retained, but SOC stocks under CT were consistently lower in the surface $400 \mathrm{~kg} \mathrm{~m}^{-2}$. Over the last 18 years, CT lost $0.83 \pm 0.2 \mathrm{~kg} \mathrm{of} \mathrm{C} \mathrm{m}^{-2}$ while ZT gain 1.98 \pm 0.3 and PRB gain $0.97 \pm 0.2 \mathrm{~kg}$ of $\mathrm{C} \mathrm{m}^{-2}$ in the $1200 \mathrm{~kg}$ of soil m $\mathrm{m}^{-2}$ profile. These findings suggest that carbon sequestration can be improved if treatments $\mathrm{T}_{4}$ or $\mathrm{T}_{6}$ are used in lieu of $\mathrm{T}_{7}$, respectively. 


\section{Introduction}

Soil organic matter, as indicated by $\mathrm{C}$ and $\mathrm{N}$ levels, is an important component of soil quality and productivity. Increasing soil organic matter through enhanced $\mathrm{C}$ and $\mathrm{N}$ sequestration can also reduce the potentials for global warming by mitigating greenhouse gas emissions and $\mathrm{N}$ leaching by increasing $\mathrm{N}$ storage in the soil (Lal et al., 1995). Carbon and $\mathrm{N}$ sequestration usually occur when nonharvested crop residues, such as stems, leaves, and roots, are placed at the soil surface due to no-tillage (Sainju et al., 2007).

Soil and crop management practices can alter the quantity, quality, and placement of crop residues in the soil, thereby influencing soil $\mathrm{C}$ and $\mathrm{N}$ storage, microbial biomass and activity, and $\mathrm{N}$ mineralization-immobilization (Sainju et al., 2006b). Residue placement in the soil under different tillage systems can influence $\mathrm{C}$ and $\mathrm{N}$ levels by affecting soil aggregation, aeration, and $\mathrm{C}$ and $\mathrm{N}$ mineralization (Halvorson et al., 2002b). Quantity and quality of carbon inputs, cropping intensity, soil and crop management practices affect carbon and nitrogen dynamics and carbon sequestration in different soil depths (Rahman, 2013).

The soil carbon is capable of enhancing agricultural sustainability and serving as a potential sink of atmospheric $\mathrm{CO}_{2}$. Carbon dioxide abundance in the atmosphere along with other greenhouse gases caused global warming and climate change. Sequestration of carbon in soils may potentially mitigate the negative effect of global warming on agriculture. Intensified rice based cropping systems consume more inputs and thereby release more $\mathrm{CO}_{2}$ and sequester less carbon in soil (Bhatia et al., 2011). Soil and cop management practices and organic materials that increase the stocks of soil carbon may have profound effects on climate mitigation
(Soderstorm et al., 2014). Because of large pool sizes and inherent spatial variability, soil organic C (SOC) and total N (STN) (slow or non-labile fractions) change slowly with management practices. Therefore, measurements of SOC and STN alone may not adequately reflect changes in soil quality and nutrient status (Ghimire et al., 2012).

Active (or labile) $\mathrm{C}$ and $\mathrm{N}$ fractions, such as potential $\mathrm{C}$ and $\mathrm{N}$ mineralization (PCM and PNM) that indicate microbial activity and $\mathrm{N}$ mineralization, and microbial biomass $\mathrm{C}$ and $\mathrm{N}$ (MBC and MBN) that refer to microbial biomass and $\mathrm{N}$ immobilization, change seasonally (Franzluebbers and Arshad, 1997). Similarly, particulate organic C and N (POC and $\mathrm{PON}$ ) that represent coarse organic matter and considered as intermediate $\mathrm{C}$ and $\mathrm{N}$ levels between slow and active fractions, provide substrates for microbes and influence soil aggregation (Six et al., 1999). Although active $\mathrm{C}$ and $\mathrm{N}$ fractions in the soil can change more rapidly than the other fractions, these fractions sometime may not be readily changed within a crop growing season due to high variability in soil properties within a short distance in the field or in regions with limited precipitation, cold weather, and a short growing season (Sainju et al., 2006b).

We hypothesized that surface placement of crop residue (a simulation of no-tillage in the field) under wheat crop can increase soil labile and non-labile $\mathrm{C}$ and $\mathrm{N}$ fractions and sustain crop yields compared to residue incorporation into the soil or removal of residue (a simulation of conventional tillage). Our objectives were to: (1) evaluate the effects of residue placement on crop yields, residue $\mathrm{C}$ and $\mathrm{N}$ losses, and soil labile and non-labile $\mathrm{C}$ and $\mathrm{N}$ fractions within a growing season and (2) determine if soil $\mathrm{C}$ and $\mathrm{N}$ fractions change more readily in the crop residue (a simulation of no-tillage in the field) within a growing season. 


\section{Materials and Methods}

\section{Experimental site}

The long-term field experiments was initiated in 2000 at Sardar Vallabhbhai Patel University of Agriculture \&Technology, Meerut research farm $\left(29^{\circ} \quad 04^{\prime}, \quad \mathrm{N}\right.$ latitude and $77^{0} \quad 42^{\prime}$ ' $\mathrm{E}$ longitude a height of $237 \mathrm{~m}$ above mean sea level) U.P., India. During the 16 -year period of field experiment, mean weekly maximum and minimum air temperature for the crop seasons were recorded ranged from 16.3 to $36.4^{\circ} \mathrm{C}$ and 5.2 to $19.6^{\circ} \mathrm{C}$, respectively. The area receives an average annual rainfall of 695 $\mathrm{mm}$ (constituting $44 \%$ of pan evaporation) of which about $80 \%$ is received during the monsoon period.

\section{Soil of the experimental site}

A composite soil sample was collected from the experimental field to study the contents of available $\mathrm{N}, \mathrm{P}$ and $\mathrm{K}, \mathrm{pH}$, electric conductivity, organic carbon content and some physical properties of the soil (Table 1). The soil analysis revealed that the soil was sandyloam with 55, 18, and 27\% sand, silt, and clay, respectively, Typic Ustochrept; non-saline (EC $0.42 \mathrm{dS} \mathrm{m}^{-1}$ ) but mild alkaline in reaction ( $\mathrm{pH}$ 7.98). The soil (0-15 cm depth) initially had $4.1 \mathrm{~g} \mathrm{~kg}^{-1}$ of SOC and 16.4, 96, and 14.5 $\mathrm{kg} \mathrm{ha}^{-1}$ of available $\mathrm{P}, \mathrm{K}$, and $\mathrm{S}$, respectively.

\section{Experimental details}

The experiment was laid out in a split plot design keeping seven tillage crop establishment methods $\mathrm{T}_{1^{-}} \mathrm{ZT}$ without residue, $\mathrm{T}_{2^{-}}, \mathrm{ZT}$ with $4 \mathrm{t}$ residue retained, $\mathrm{T}_{3^{-}}$ $\mathrm{ZT}$ with $6 \mathrm{t}$ residue retained, $\mathrm{T}_{4}$ - $\mathrm{PRB}$ without residue, $\mathrm{T}_{5^{-}} \mathrm{PRB}$ with $4 \mathrm{t}$ residue retained, $\mathrm{T}_{6^{-}}$ $\mathrm{PRB}$ with $6 \mathrm{t}$ residue retained, $\mathrm{T}_{7^{-}}$ Conventional tillage in main plots and five nitrogen management practices were $F_{1^{-}}$ Control (no N-P-K fertilizers or organics; $\mathrm{F}_{2}$ -
$50 \%$ NPK; $\mathrm{F}_{3}-100 \%$ NPK; $\mathrm{F}_{4}-100 \%$ organic as sole FYM; $\mathrm{F}_{5^{-}} \quad 50 \% \quad \mathrm{NPK}+50 \%$ $\mathrm{NPK}$ (foliar); $\mathrm{F}_{6^{-}} \quad 50 \%$ organic (FYM) + $50 \% \mathrm{NPK} ; \mathrm{F}_{7^{-}}$Farmer's practice $(180 \mathrm{~kg} \mathrm{~N}+$ $60 \mathrm{~kg} \mathrm{P}_{2} \mathrm{O}_{5} \mathrm{ha}^{-1}$ only) allotted to sub-plots in a split-plot design and replicated thrice. The gross and net plot sizes were $8 \mathrm{~m} \times 3.2 \mathrm{~m}$ and $6.0 \mathrm{~m} \times 2.0 \mathrm{~m}$, respectively and treatments were superimposed in the same plot every year to study the cumulative effect of treatments. Farmyard manures (FYM) was applied on the basis of $\mathrm{N}$ equivalent basis in $100 \%$ RDN. The $\mathrm{N}, \mathrm{P}_{2} \mathrm{O}$, and $\mathrm{K}_{2} \mathrm{O}$ in FYM, and rice straw, wheat straw was 0.5, 0.25, 0.3; $0.5, \quad 0.23, \quad 1.14$ and $0.5,0.25, \quad 1.21$, respectively.

The tillage and crop establishment methods comprised of (i) conventional tillage (CT): In conventional tillage there were four tillage operations. The first tillage was performed in the pre-monsoon season (April/May) and the second one was performed in May/June, some 20-25 days after the first tillage. The third tillage was conducted during June and the fourth rice harvest (October/November) at deeper depth $(>15 \mathrm{~cm})$ using a tractor drawn cultivator. Similar tillage operations were followed for the wheat crop.; (ii) Permanent Raised Beds (FIRB): seeds were drilled, $5 \mathrm{~cm}$ deep, over rice harvested bed tops, in six rows, after superficial reshaping using plots using inclined plate zero-till cum raised bed planter (FIRB); and (iii) zero tillage (ZT): seeds were drilled, $5 \mathrm{~cm}$ deep, on untilled rice harvested plots using inclined plate zero-till seed drill. The residue management consisted of (i) residue retention (RR): The $40 \mathrm{~cm}$ stubbles of preceding crop were left at harvest and chopped rice straw of size $15-20 \mathrm{~cm}$ was applied in 4 tha $^{-1}$ and $6 \mathrm{t} \mathrm{ha}^{-1}$ as mulch manually on the same day after sowing of wheat in each year. (ii) Residue removal (RO): preceding crop was harvested from ground level leaving about $5 \mathrm{~cm}$ stubbles. The nutrient management practices one-third of $\mathrm{N}$ and 
entire $\mathrm{P}, \mathrm{K}$ were applied at the time of transplanting/sowing and remaining $\mathrm{N}$ was top dressed in 2 equal splits at maximum tillering and panicle/ear emergence. The FYM was incorporated in the soil one week before transplanting/ sowing of the crops. Both crops were grown under assured irrigated conditions with recommended agronomic practices.

\section{Soil sampling and processing}

After wheat harvest (May 2018), two sets of triplicate undisturbed soil cores were collected from 0 to 5 and 5 to $15 \mathrm{~cm}$ soil depths using a core sampler $(7.5 \mathrm{~cm}$ diameter $)$ from all treatments to determine the cumulative effect of application of 18 years of treatments on SOC dynamics. Bulk density was determined using one sample set. Samples from individual plots (the second set) were thoroughly mixed, air-dried, and passed through a $5 \mathrm{~mm}$ sieve. We found no aggregates $>5 \mathrm{~mm}$ diameter. Airdried samples were placed in plastic bags and stored at ambient laboratory temperature. A soil sub-sample was taken from both depths and analyzed for soil aggregation and total SOC.

\section{Particulate organic carbon}

For the POM fraction, $50 \mathrm{~g}$ of air-dried soil sample was submerged in deionized water for $30 \mathrm{~min}$ to promote slaking of aggregates. Then, the mixture was poured onto a $250-\mu \mathrm{m}$ sieve inside a cylinder and reciprocally shaken at $120 \mathrm{rpm}$ with $50 \mathrm{glass}$ beads of $10-\mathrm{mm}$ diameter. The micro-aggregates that passed through the $250-\mu \mathrm{m}$ sieve were collected in a bottom sieve of $25-\mu \mathrm{m}$. The fraction retained on the $250-\mu \mathrm{m}$ sieve consisted of coarse material (POM and sand from 250 to 2,000$\mu \mathrm{m})$ and was labeled as coarse POM. The aggregates retained on the $25-\mu \mathrm{m}$ sieve (having size from 25 to 250-lm) were dispersed by shaking for $18 \mathrm{~h}$ with $25 \mathrm{ml}$ of $0.5 \mathrm{~g} \mathrm{ml}^{-1}$ sodium hexametaphosphate and 12 glass beads of 4-mm diameter in a 50-ml centrifuge tube to isolate the fine POM (Cambardella and Elliott, 1992).

\section{Microbial biomass carbon}

For the estimation of soil microbial biomass $\mathrm{C}$ and $\mathrm{N}$ by the chloroform fumigation and incubation method Horwath and Paul, (1994) soil moisture was adjusted to $55 \%$ field water capacity, pre-incubated at $25^{\circ} \mathrm{C}$ for 7 days in the dark, and each soil sample was subdivided into two subsamples for fumigated and nonfumigated treatments. For MBC, soil samples, equivalent to $30 \mathrm{~g}$ dry weight, were fumigated with $\mathrm{CHCl}_{3}$ for $24 \mathrm{~h}$ at $25^{\circ} \mathrm{C}$.After removing the $\mathrm{CHCl}_{3}$, each soil sample was incubated at $25^{\circ} \mathrm{C}$ for a period of 10 days in closed tight Mason jar along with vials containing $1.0 \mathrm{ml} 2$ $\mathrm{M} \mathrm{NaOH}$. The flush of $\mathrm{CO}_{2}-\mathrm{C}$ released upon fumigation was determined from titration with $\mathrm{HCl}$. The MBC was computed using Eq. (2):

$\operatorname{MBC}\left(\mathrm{mg} \mathrm{kg}^{-1}\right)=(\mathrm{Fc}-\mathrm{UFc}) / \mathrm{Kc}(1)$

Where, $\mathrm{Fc}$ is $\mathrm{CO}_{2}$ evolved from the fumigated soil, UFc is $\mathrm{CO}_{2}$ evolved from the unfumigated soil, and $\mathrm{Kc}$ is a factor with value of 0.41 Anderson and Domsch, (1978).

\section{Estimation of carbon in soil}

Soil organic carbon was determined by wet digestion with potassium dichromate along with 3:2 $\mathrm{H}_{2} \mathrm{SO}_{4}: 85 \% \mathrm{H}_{3} \mathrm{PO}_{4}$ digestion mixture in a digestion block set at $1200 \mathrm{C}$ for $2 \mathrm{~h}$ (Snyder and Trofymow, 1984).

A pre-treatment with $3 \mathrm{ml}$ of $1 \mathrm{~N} \mathrm{HCl} \mathrm{g}^{-1}$ of soil was used for removal of carbonate and bicarbonate. The SOC concentration of the soil samples was obtained from the following calculation (Eq. [4])

SOC concentration $=$ Total $\mathrm{C}-$ Inorganic $\mathrm{C}$ (2) 
The total SOC stock of the profile expressed as $\mathrm{Mg} \mathrm{ha}^{-1}$ for each of the five depths $(0-15$, $15-30,30-60,60-80$, and $80-100 \mathrm{~cm}$ ) was computed by multiplying the SOC concentration $\left(\mathrm{g} \mathrm{kg}^{-1}\right)$ (obtained by

SOC = LECOC-HCl C) by the bulk density $\left(\mathrm{Mg} \mathrm{m}^{-3}\right)$ and depth $(\mathrm{cm})$.

\section{Calculations for CARBON BUDGETING}

Carbon budgeting was computed by using the following equations:

$$
C_{\text {restoration }}(\%)=\frac{C_{f e r t+0 r g o r} C_{f e r t}-C_{\text {cont }}}{C_{\text {cont }}} \times 100
$$

Where $\mathrm{C}_{\text {Fert }}+$ org represent $\mathrm{C}$ in Fertilizer + FYM treatments and $\mathrm{C}_{\text {fert }}$ and $\mathrm{C}_{\text {cont }}$ is the $\mathrm{C}$ in fertilizer and control treatments, respectively.

$$
\begin{aligned}
& C_{\text {build up rate }}\left(M g C_{\text {ha }^{-1}}\right) \\
& =\frac{C_{\text {fert }+ \text { orgor }} C_{\text {fert }}-C_{\text {cont }}}{\text { Year of experimentation }} \\
& C_{\text {stabilization }(\%)}=\frac{C_{\text {fert }+ \text { org }}-C_{\text {fert }}}{C_{\text {org }}} \times 100
\end{aligned}
$$

Where $\mathrm{C}$ org represents $\mathrm{C}$ applied through organic material (i.e., FYM)

$$
\begin{aligned}
& C_{\text {sequestered }}\left(\mathrm{MgC}_{\mathrm{ha}^{-1}} \text { soil }\right)= \\
& S O C_{\text {current }}-S O C_{\text {init }} \text { (6) }
\end{aligned}
$$

Where SOC current and SOC init indicate the SOC stocks in 2017 (current) and that at the initiation of the long - term experiment (in 2000). Positive and negative values indicate gains and losses in SOC stocks, respectively. Carbon retention efficiency (CRE) was calculated by the following relationship following Bhattacharyya et al., (2009b):
$\operatorname{CRE}(\%)=\left[\frac{50 C_{\text {final }}-50 C_{\text {initial }}}{E C l}\right] \times 100$

Where, $\mathrm{SOC}_{\text {final }}$ and $\mathrm{SOC}_{\text {initial }}$ represent $\mathrm{SOC}$ $\left(\mathrm{Mg} \mathrm{ha}{ }^{-1}\right)$ in the final and initial soils, respectively, and ECI is cumulative estimated $\mathrm{C}$ input $\left(\mathrm{Mg} \mathrm{ha}^{-1}\right)$ to soil between the initial and final year of experimentation.

Carbon sequestration potential with use of NPK fertilizer and FYM (CSP- INM)

The CSP of the RDN+FYM treatment over the NPK treatment was calculated using the following equation:

CSP- INM $=$ SOC $-\mathrm{NPK}+\mathrm{FYM}-\mathrm{SOC}-\mathrm{NPK}$

Where CSP- INM is CSP with use of NPK and FYM $\left(\mathrm{Mg} \mathrm{ha}^{-1}\right)$, SOC- NPK+FYM is final $\mathrm{SOC}$ in the NPK+FYM treatment $(\mathrm{Mg}$ $\mathrm{ha}^{-1}$ ) and SOC- NPK is final SOC in the NPK treatment $\left(\mathrm{Mg} \mathrm{ha}^{-1}\right)$.

Rate of C sequestration (CSP Rate) in $\mathrm{Mgha}^{-1}$ $\mathrm{yr}^{-1}$ was calculated as

$\operatorname{CSP}-$ Rate $=\frac{C S P-S}{D}(9)$

Where CSP- S is CSP in a particular scenario $\left(\mathrm{Mg} \mathrm{ha}^{-1}\right)$ and $\mathrm{D}$ is the duration of the long term experiment (yr).

Carbon sequestration efficiency (CSE) was calculated a

CSE $=\frac{\text { CSP }- \text { Rate-FYM }}{C-F Y M}$

Where CSP- Rate -FYM is C sequestration rate in the FYM treatment $\left(\mathrm{Mg} \mathrm{ha}^{-1} \mathrm{yr}^{-1}\right)$, and C- FYM is amount of C added through FYM $\left(\mathrm{Mg} \mathrm{ha}^{-1} \mathrm{yr}^{-1}\right)$. 


\section{Sustainable yield index}

Total crop productivity of rice and wheat was calculated through a SYI using yield-data of 16 yr. This was done to adjust any annual variations in the yield and to highlight the relative productivity of the treatments for the entire experimental period. The SYI is defined according to Eq. [11]:

SYI $=^{\frac{y-p}{\max }}(11)$

Where $\mathrm{Y}$ is the estimated average yield of a practice across the years, ó is its estimated standard deviation, and $Y_{\max }$ is the observed maximum yield in the experiment during the years of cultivation (Singh et al., 1990).

\section{Measurement of Enzyme activities}

Soil enzyme activities (invertase, urease, and reductase) were measured. The detailed methods for the enzyme analyses are as follows: Invertase activity was determined by titration of sodium thiosulfate $\left(\mathrm{Na}_{2} \mathrm{~S}_{2} \mathrm{O}_{3}\right)$ as described by Guan (1986). Briefly, $5 \mathrm{~g}$ of soil was incubated for $24 \mathrm{~h}$ at $37^{\circ} \mathrm{C}$ with $15 \mathrm{~mL}$ of $8 \%$ sucrose, $5 \mathrm{~mL}$ of phosphate buffer at $\mathrm{pH}$ 5.5 , and $0.75 \mathrm{~mL}$ of toluene. After filtration, an aliquot of $1 \mathrm{~mL}$ of the filtrate was added to a 50-mL flask and heated with $3 \mathrm{~mL}$ of $3,5-$ dinitrosalicylic acid at $100^{\circ} \mathrm{C}$ for $5 \mathrm{~min}$, and then the color was measured at $508 \mathrm{~nm}$.

Urease activity was determined using urea as the substrate. Five grams of soil, $10 \mathrm{~mL}$ of $10 \%$ urea solution, and $20 \mathrm{~mL}$ of citrate buffer (pH 6.7) were added to a 50- $\mathrm{mL}$ flask and incubated at $37^{\circ} \mathrm{C}$ for $2 \mathrm{~h}$. After filtration, an aliquot of $3 \mathrm{~mL}$ of the filtrate was added to a $50-\mathrm{mL}$ flask, and then $4 \mathrm{~mL}$ of sodium phenolate and $3 \mathrm{~mL}$ of sodium hypochlorite were added. The color developed at room temperature was measured at $578 \mathrm{~nm}$ (Guan, 1986).

\section{Statistical analysis}

Statistical analysis was performed by windows based SPSS programme (ver. 16.0, SPSS Inc. 1996) to determine the statistical significance of treatment effects. Duncan's Multiple Range Test (DMRT) was used to compare means through least significant difference (LSD). The $5.0 \%$ probability level is regarded as statistically significant.

\section{Results and Discussion}

\section{Yield and sustainable yield index (SYI)}

Grain yield of rice and wheat differed among tillage crop residue practices and fertilizer treatments. Yield trends over 18 yr of cropping indicated similar initial yields $(2-3$ yr) among tillage crop establishment, mineral fertilization and INM with organic manure, but significant differences occurred during the later periods. Significantly higher SYI was observed with the application of FYM either alone or in combination with mineral fertilizers and treatments $T_{6}, T_{2}$ compared to $\mathrm{F}_{1}$. The highest SYI (\% for rice and wheat, respectively) was observed in $\mathrm{F}_{6}$ with $\mathrm{T}_{6}$ $(6.1 ; 6.2)$ followed by $\mathrm{F}_{4}(5.7 ; 5.9)$ with $\mathrm{T}_{4}$, and the lowest was in $F_{1}(3.3 ; 3.1)$ (Table 2). This trend is mainly due to a high moisture retention capacity in FYM-treated plots with wide raised beds crop establishment compared with those receiving mineral fertilizers with ZT drill seeding rice and dry CT drill seeding wheat and also due to a slow N-releasing capacity of FYM (Bossche et al., 2009).

\section{Soil organic carbon pool}

Total SOC storage (on an equivalent-depth basis) in the ZT plots was about $21.7 \%$ higher than in $\left(\mathrm{T}_{7}\right) \mathrm{CT}$ plots $\left(30.96 \mathrm{Mg} \mathrm{ha}^{-1}\right)$ in the 0 to $30-\mathrm{cm}$ soil layer and nearly $15.9 \%$ higher in the PRB plots than in $\left(\mathrm{T}_{7}\right) \mathrm{CT}\left(28.83 \mathrm{Mg} \mathrm{ha}^{-1}\right)$ in the 0 - to $30-\mathrm{cm}$ soil layer (Table 2). Tillage 
had significant impact on SOC storage in the $0-$ to $30-\mathrm{cm}$ soil layer. On an equivalent-mass basis, plots under ZT and PRB with residue retained had significantly higher SOC stock than CT plots only in the $0-30 \mathrm{~cm}$ soil layer after $18 \mathrm{yr}$ of rice-wheat cropping (Table 2). Change in SOC pool is a process of soil establishing a new balance between inputs and outputs under different treatments (Lal et al., 1998). Generally, no-tillage with residue left in place has the potential for sequestering more SOC than conventional tillage in the upper soil depths for two reasons: (i) tillage destroys the protection provided by crop residue on the surface; and (ii) increases the oxidization of SOM which could be avoided by no-tillage treatment.

In the ZT and PRB systems, stubble was left on the soil surface, implying much slower stubble decomposition and protection of the soil surface from raindrop impact and wind erosion (Chivenge et al., 2007). These factors were probably very helpful in attaining higher SOC content in the ZT and PRB plots. Higher SOC content in the $0-30 \mathrm{~cm}$ soil layer of a ZT and PRB systems might have led to more large macro-aggregates, which were more stable (Singh and Malhi, 2006). All these factors led to the accumulation (and prevention of loss) of SOC in the ZT plots in the upper soil layer. Nutrient management practices had a significant impact on SOC storage in the 0- to 30-cm soil layers (Table 2). Plots under $\mathrm{F}_{4}$ and $\mathrm{F}_{6}$ had similar SOC stocks, but had significantly higher SOC stocks than $F_{1}$ and $F_{2}$ plots in the 0 - to $30-\mathrm{cm}$ depth layer and higher SOC stocks compared with $\mathrm{F}_{7}$ plots only in the $\mathrm{F}_{6}$ plots.

\section{Water Soluble Carbon}

The distribution of soil mass among the size classes of water stable carbon (WSC) was strongly influenced by tillage crop residue practices in both the soil depths $(0-15 \mathrm{~cm}$ and
$15-30 \mathrm{~cm})$. WSC was found to be $3.74 \%$ higher in surface soil than in sub-surface soil (Table 3 ). In both the depths, $\mathrm{T}_{6}$ treatment had the highest WSC as compared to the other treatments studied. Compared to conventional tillage, PRB and ZT coupled with 6 tha $^{-1} \mathrm{CR}$ increased $39.6 \%$ WSC in surface soil and $37.4 \%$ in sub surface soil. Among all the treatments, $\mathrm{T}_{6}$ had significantly higher $(20.15 \%)$ proportion of WSC than the other treatments compared. Irrespective of tillage practices, residue retention resulted in $26.39 \%$ and $22.17 \%$ higher WSC as compared to the non-residue treatments in surface and subsurface soil, respectively. The WSC content in surface soil $(0-15 \mathrm{~cm})$ was significantly higher in $50 \% \mathrm{RDN}$ as $\mathrm{CF}+50 \% \mathrm{RDN}$ as FYM $\left(\mathrm{F}_{5}\right)$ treatment $\left(32.5 \mathrm{mg} \mathrm{kg}^{-1}\right)$ followed by $00 \%$ RDN as FYM $\left(\mathrm{F}_{6}\right)\left(31.6 \mathrm{mgkg}^{-1}\right)$ and least in unfertilized control plot $\left[\left(\mathrm{F}_{1}\right)\right.$ (21.9 $\mathrm{mgkg}^{-1}$ ) (Table 3)]. However, similar significant effect was observed in sub-surface soil $(15-30 \mathrm{~cm})$ and the magnitude was relatively lower. The increase in WSC in 0-15 $\mathrm{cm}$ soil depth was 37.2 and $32.9 \%$ in $50 \%$ $\mathrm{RDN}$ as $\mathrm{CF}+50 \% \mathrm{RDN}$ as $\mathrm{FYM}\left(\mathrm{F}_{5}\right)$ and $100 \%$ RDN as FYM $\left(\mathrm{F}_{4}\right)$ treated plots over control. WSC, an active pool of organic C, serves as both source and sink for mineral nutrients and organic substrates in a shortterm, and as a catalyst for conversion of plant nutrients from stable organic form over a longer period thereby influencing crop productivity and nutrient cycling.

\section{Soil microbial biomass carbon}

The level of MBC was indistinguishable between the $\mathrm{CT}$ and $\mathrm{ZT}$ without residue retention regimes and was markedly lower under these regimes than under ZT with residue retention and $\mathrm{PRB}$ with residue retention (Table 3). Changes in MBC can indicate the effects of management practices on soil biological and biochemical properties. The higher MBC we observed in the ZT and 
PRB with residue retention plots than the CT plot under the RWCS suggests that abandonment of the cropland had substantial beneficial effects on the activity of microbial organisms probably caused by the accumulation of organic $\mathrm{C}$ compounds at the soil surface. A possible reason for this difference is that in the absence of growing plants other labile $\mathrm{C}$ fractions may provide food for microbes, and thus maintain MBC. Another possible reason could be related to the soil moisture status. Under the CT treatment, in which biomass production would inevitably deplete much more soil moisture, the microbes in the plot would be stressed at the time of sampling (wheat maturity).

The microbial biomass carbon (MBC) is an important component of the SOM that regulates the transformation and storage of nutrients. The soil MBC regulates all SOM transformations and is considered to be the chief component of the active SOM pool. It is evident that the MBC contents in both surface and sub-surface soil were significantly higher in plots receiving 50\% $\mathrm{RDN}$ as $\mathrm{CF}+50 \% \mathrm{RDN}$ as $\mathrm{FYM}\left(\mathrm{F}_{5}\right)$ and $100 \% \mathrm{RDN}$ as FYM $\left(\mathrm{F}_{4}\right)$ treated plots compared to $100 \% \mathrm{RDN}$ as $\mathrm{CF}$ $\left(\mathrm{F}_{3}\right)$ fertilizer and unfertilized control plots (Table 3). The values of MBC in surface soil varied from $116.8 \mathrm{mgkg}^{-1}$ in unfertilized control plot to $424.1 \mathrm{mgkg}^{-1}$ in integrated nutrient use of $50 \% \mathrm{RDN}$ as $\mathrm{CF}+50 \% \mathrm{RDN}$ as FYM $\left(\mathrm{F}_{5}\right)$ plots, respectively; while it varied from $106.6 \mathrm{mgkg}^{-1}$ (control) to $324.9 \mathrm{mgkg}^{-1}$ $\left(100 \% \mathrm{RDN}\right.$ as FYM $\left.\mathrm{F}_{5}\right)$ in sub-surface $(15-$ $30 \mathrm{~cm}$ ) soil layer. The values of $\mathrm{MBC}$ increased by 58.4 and $72.5 \%$ under $50 \%$ RDN as $\mathrm{CF}+50 \% \mathrm{RDN}$ as $\mathrm{CF}$ foliar $\left(\mathrm{F}_{5}\right)$ treatment in surface soil over control. While, there were 14.5 and $43.4 \%$ increase of MBC over $100 \%$ $\mathrm{RDF}$ as $\mathrm{CF}\left(\mathrm{F}_{3}\right)$ fertilizer, respectively. The highest value of MBC due to integrated use of FYM and RDN fertilizer might be due to higher turn-over of root biomass produced under 50\% RDN as CF+ 50\% FYM treatment.
Application of $100 \%$ RDN as CF fertilizer is not only required for better growth of the crop but also required for synthesis of cellular components of microorganisms. Therefore, higher root biomass under $50 \%$ RDN as $\mathrm{CF}+50 \% \mathrm{FYM}$ fertilizer treatment helped in increasing $\mathrm{MBC}$ over other treatments. Although MBC content in soil represent a small fraction i.e. about $2-4 \%$ of TOC, however, variation in this pool due to management and cropping systems indicate about the quality of soil, because the turn-over of SOM is controlled by this pool of SOC which can provide an effective early warning of the improvement or deterioration of soil quality as a result of different management practices. In our study, MBC was highest in the 50\%inorganic fertilizer+50\% FYM treatment. The increase of MBC under FYM amended soils could be attributed to several factors, such as higher moisture content, greater soil aggregation and higher SOC content. The FYM amended plots provided a steady source of organic $\mathrm{C}$ to support the microbial community compared to inorganic fertilizer treated plots. Generally, FYM applied to soil has long been employed to enhance favorable soil conditions. This view is consistent with the observation of Hao et al., (2008) who observed that the microbial biomass was considerably greater in soils receiving FYM along with NPK fertilizer than in plots receiving merely NPK fertilizer in three subtropical paddy soils. Mandal et al., (2007) also reported that the microbial biomass was greater in soils due to addition of straw plus inorganic NPK for 34 years than that of inorganic NPK fertilizers.

\section{Light fraction of carbon}

The labile fraction carbon (LFC) is considered as a useful approach for the characterization of SOC resulting from different soil management practices including cropping systems and application of organic and inorganic sources 
of nutrients. The values of LFC in surface soil were $81.3,95.7,107.8,155.2,128.8,177.8$ and $52.7 \mathrm{mgkg}^{-1}$ in ZT and PRB without residue retention, $\mathrm{ZT}$ and $\mathrm{PRB}$ with $4 \& 6$ tha $^{-}$ 1 residue retention and conventional tillage (CT) treatments, respectively (Table 3). In 15$30 \mathrm{~cm}$ layer, the increasing trends in LFC content due to use of tillage practices and residue retention were similar to those observed in $0-15 \mathrm{~cm}$ layer; however, the magnitude was relatively lower (Table 3 ). The LFC content of the soil increased with the application of fertilizers and/or FYM (Table $3)$. In the surface layer, the organic treatment accumulated $51.5 \%$ greater LFC $(183.9 \mathrm{mg}$ $\mathrm{kg}^{-1}$ ) followed by $44.4 \%$ greater in integrated $\left(160.5 \mathrm{mgkg}^{-1}\right)$ and $27.7 \%$ greater in RDN (123.5 mg kg-1) as compared to the control treatment. In general, the management practices which accumulate greater amounts of SOC, such as organic residue additions (Janzen et al., 1992) and nutrient applications (Nyborg et al., 1999), are considered to increase the proportion of LFC in soil.

\section{Particulate organic matter fractions}

The largest differences among tillage systems were found at the soil surface (Table 3 ). In the upper $15 \mathrm{~cm}$ depth, the $\mathrm{fOM}-\mathrm{C}$ content was between 1.2 and 3 times higher under ZT and $\mathrm{PRB}$ with residue retained than under $\mathrm{CT}$. The lower ${ }_{c}$ POM-C content under ZT than under $\mathrm{CT}$ in the two soil layers (2-2.6 times less) can be explained by the farmer's practice of removing crop residues from the ZT field (Table 3). These values represent between 24 and $191 \%$ more ${ }_{\mathrm{f}} \mathrm{POM}-\mathrm{C}$ with residue retained $\mathrm{ZT}$, averaging about $105 \%$ more. For ${ }_{\mathrm{c}} \mathrm{POM}$, this range varied from $48 \%$ less to $187 \%$ more, with an average value of $74 \%$ more. For both ${ }_{\mathrm{c}} \mathrm{POM}$ and ${ }_{\mathrm{f}} \mathrm{POM}$ fractions, the decreasing pattern in $\mathrm{OC}$ concentration with depth was more prominent under conservation tillage, especially ZT, in such a way that the average concentrations in the $0-40 \mathrm{~cm}$ profile were not significantly different from those under CT. The marked stratification of POM$\mathrm{C}$ is generally observed under continuous ZT management (Salvo et al., 2010) and is produced by the maintenance of crop residues at the soil surface and the absence of soil disturbance.

The POM-C, disproportionately to its small contribution to total SOC, has a large effect on nutrient-supplying capacity and structural stability of soils, and for these reasons it is considered a key attribute of soil quality (Haynes, 2005). Of the two POM fractions isolated in the present study, ${ }_{\mathrm{f}} \mathrm{POM}$ was, in general, more sensitive to soil tillage and land use than ${ }_{c} \mathrm{POM}$. On the other hand, ${ }_{\mathrm{c}} \mathrm{POM}$ is more dependent on plant derived $\mathrm{C}$ inputs and, therefore, more variable in time and space (also in depth) than ${ }_{\mathrm{f}} \mathrm{POM}$ (Duval et al., 2013). For those reasons, ${ }_{\mathrm{f}} \mathrm{POM}$ can be considered more reliable and useful indicator of soil changes associated with tillage and crop residue management.

In the present study, both the ${ }_{\mathrm{c}} \mathrm{POM}$ and ${ }_{\mathrm{f}} \mathrm{POM}$ increased with the application of fertilizers/or FYM (Table 3). At $0-15 \mathrm{~cm}$ depth, cPOM increased more than $100 \%$ in both treatments receiving FYM (integrated, organic) as compared to an increase of $45 \%$ in NPK over the control treatment. A similar trend was observed for ${ }_{\mathrm{f}} \mathrm{POM}$, where the organic treatment accumulated $88 \%$ greater ${ }_{\mathrm{f}} \mathrm{POM}$ $\left(1,064 \mathrm{mg} \mathrm{kg}^{-1}\right)$ than the control. This was followed by an increase of $76 \%$ in integrated (994 $\mathrm{mgkg}^{-1}$ ) and 39\% in NPK (785 $\mathrm{mgkg}^{-1}$ ) over the control. The application of fertilizers and manures increased the POM due to the production of greater production of the plant biomass and excretion of root exudates (Malhi and Gill 2002). A similar trend was observed in the sub-surface layer, however, the contents of both ${ }_{c} \mathrm{POM}$ and ${ }_{\mathrm{f}} \mathrm{POM}$ fractions were comparatively lower. The sum of ${ }_{\mathrm{f}} \mathrm{POM}$ and ${ }_{\mathrm{c}} \mathrm{POM}$ as a proportion of SOC ranged from 25 
to $35 \%$ in the surface layer and 24 to $33 \%$ in the sub-surface layer. Franzluebbers and Arshad (1997) also observed a decrease of POM with an increase in soil depth.

\section{Soil organic carbon patterns}

The SOC concentration differed significantly $(\mathrm{p}<0.05)$ among treatments and depths (Table 4). The highest SOC concentration of $5.8 \mathrm{~g}$ $\mathrm{kg}^{-1}$ in the surface layer $(0-15 \mathrm{~cm})$ was observed in $\mathrm{F}_{6}$ followed by that in $\mathrm{F}_{4}\left(5.4 \mathrm{gkg}^{-}\right.$ $\left.{ }^{1}\right)$ treatment. All plots treated with organic amendments contained higher SOC concentration in the surface and sub-soil compared with those not receiving any organics. The SOC concentration also improved with the application of $\mathrm{F}_{3}\left(5.1 \mathrm{~g} \mathrm{~kg}^{-}\right.$ $\left.{ }^{1}\right)$ and $F_{5}\left(4.9 \mathrm{~g} \mathrm{~kg}^{-1}\right)$.In contrast, the SOC concentration increased with the application of organic materials even in the sub-soil. The mean profile SOC concentration increased from $2.8 \mathrm{~g} \mathrm{~kg}^{-1}$ in $\mathrm{F}_{7}$ to $4.4 \mathrm{~g} \mathrm{~kg}^{-1}$ in $\mathrm{F}_{6}$. However, no increase in SOC concentration was observed in treatment $F_{2}$. It is widely recognized that the use of organic manures and compost enhances the SOC concentration more than does the use of the same amount of nutrients applied as chemical fertilizers (Lorenz and Lal, 2005). Tillage systems were observed to lead to differences in SOC beginning in the third year after a change in management practice, followed by larger increase in subsequent years. In 2004-05, the SOC content was $11 \%$ higher under $\mathrm{T}_{6}$ than $\mathrm{T}_{7}$, and $10 \%$ higher with $\mathrm{T}_{3}$. By the end of the 16-year period, soil organic carbon was $25 \%$ higher with $\mathrm{T}_{6}$ than $\mathrm{T}_{7}$ and $16 \%$ higher with $\mathrm{T}_{4}$ than $\mathrm{T}_{1}$. In that same time frame, the SOC content was $17 \%$ higher with $\mathrm{T}_{2}$ than $\mathrm{T}_{7}$. The soil organic carbon content in this layer was 7\% higher with minimum than conventional tillage.SOC also tended to be significantly greater under no-till in the $20-30 \mathrm{~cm}$ layer $12 \%$ and 19\% higher than with CT and MT, respectively. Naresh et al., (2015) reported that average SOC concentration of the control treatment was $0.54 \%$, which increased to $0.65 \%$ in the RDF treatment and $0.82 \%$ in the $\mathrm{RDF}+\mathrm{FYM}$ treatment. Compared to $\mathrm{F}_{1}$ control treatment the RDF+FYM treatment sequestered $0.33 \mathrm{MgC} \mathrm{ha}{ }^{-1} \mathrm{yr}^{-1}$ whereas the NPK treatment sequestered $0.16 \mathrm{Mg} \mathrm{C}^{-1} \mathrm{yr}^{-}$ 1 .

\section{Soil organic carbon distribution}

The profile SOC stock differed significantly among treatments (Table 5). The highest SOC stock of $72.2 \mathrm{Mg} \mathrm{C} \mathrm{ha-1}$ was observed in $\mathrm{F}_{6}$ with $\mathrm{T}_{6}$ followed by that of $64 \mathrm{Mg} \mathrm{C} \mathrm{ha}^{-1}$ in $\mathrm{F}_{4}$ with $\mathrm{T}_{2}>$ that in $\mathrm{F}_{3}$ with $\mathrm{T}_{4}\left(57.9 \mathrm{Mg} \mathrm{C} \mathrm{ha}^{-1}\right)>$ $\mathrm{F}_{5}$ with $\mathrm{T}_{1}\left(38.4 \mathrm{Mg} \mathrm{C}\right.$ ha $\left.^{-1}\right)=\mathrm{F}_{7}$ with $\mathrm{T}_{5}$ $\left(35.8 \mathrm{Mg} \mathrm{C} \mathrm{Ca}^{-1}\right.$ ), and the lowest $\left(19.9 \mathrm{Mg} \mathrm{C}^{-}\right.$ ${ }^{1}$ ) in $\mathrm{F}_{1}$ with $\mathrm{T}_{7}$. Relatively higher percentage increase of SOC stock was observed in $\mathrm{F}_{6}$ with $\mathrm{T}_{6}$ treatment $\left(56.3 \mathrm{Mg} \mathrm{C}^{-1}\right)$ followed by $\mathrm{F}_{4}$ with $\mathrm{T}_{2}\left(51.4 \mathrm{Mg} \mathrm{C} \mathrm{ha}^{-1}\right)$ and $\mathrm{F}_{3}$ with $\mathrm{T}_{1}$ (48.4Mg C ha ${ }^{-1}$ ). Majumder et al., (2008) reported $67.9 \%$ of C stabilization from FYM applied in a rice-wheat system in the lower Indo-Gangetic plains.

\section{Carbon restoration in soil profile}

The final SOC concentrations in both NPK and NPK+FYM treatments were higher than the control treatment (Table 6). Compared to the RDF treatment also, the NPK+FYM treatment had higher SOC concentration in all the TCE. The highest increase in SOC in the $\mathrm{NPK}+\mathrm{FYM}$ treatment was observed in $\mathrm{F}_{6}$ with TCE $\mathrm{T}_{6}$.In comparison with the control, the mean rate of SOC build-up during the 16 years of cropping was the highest in $\mathrm{F}_{6}$ with $\mathrm{T}_{6}$ (50.63\%) and the lowest in $\mathrm{F}_{1}$ with $\mathrm{T}_{7}$ $(9.79 \%)$. It was estimated that 30 per cent of applied C through FYM was stabilized, and the rest (70 per cent) was lost through oxidation. Although ploughing- induced depletion of SOC pool is widely observed (Bhattacharyya et al., 2011), the magnitude of 
depletion depends upon the geographical location, crops/ cropping systems and inherent soil properties (Mandal et al., 2007).

\section{Carbon sequestration}

Carbon sequestration potential over tillage crop residue practices of the field after sixteen crop cycle is presented on Table 7 . Highest carbon sequestration potential change $(88.2 \%)$ was found in $\mathrm{T}_{3}$ zero tillage with 6 tha $^{-1}$ residue retained plots followed by $\mathrm{T}_{2}$ zero tillage with 4 tha $^{-1}$ residue retained plots $(84.7 \%)$ and $\mathrm{T}_{6}$ permanent raised beds with 6 tha $^{-1}$ residue retained plots (80.1). The use of $\mathrm{T}_{1}$ zero tillage without residue retained and $\mathrm{T}_{4}$ permanent raised beds without residue retained for sixteen crop cycle increased carbon sequestration potential by $24.4 \%$ and $23.1 \%$ more than that of $\mathrm{T}_{7}$ conventional tillage, respectively. The final SOC concentrations in both NPK and NPK+FYM treatments were higher than the control treatment (Table 7). Compared to the NPK treatment also, the NPK+FYM treatment had higher SOC concentration in all the nutrient management practices. The highest increase in SOC in the $50 \%$ NPK by CF+50\% NPK by FYM treatment was observed.

Similar results were observed by (Mandal et al., 2007) in an organic source of nutrient such as FYM decompose slowly resulting in more SOC accumulation in soil. Dikgwatlhe et al., (2014) reported that soil management practices are amongst the most important factors influencing changes in SOC. Xue et al., (2015) found that over time, CT system generally exhibit a significant decline in SOC concentration due to destruction of the soil structure, exposing SOM protected within soil aggregates to microbial organisms. Thus, the adoption of no-till system can minimize the loss of SOC leading to higher or similar concentration compared to $\mathrm{CT}$. The rate of residue decomposition depends not only on the amount retained but also on the characteristics of the soil and the composition of the residues (Verhulst et al., 2010).

Carbon sequestration potential (CSP) i.e., increase in soil $\mathrm{C}$ stock in a treatment compared to reference treatment in different scenarios varied in the order of CSP FYM> CSP NPK (Table 7). In the CSP FYM scenario average CSP was $1.99 \mathrm{MgC} \mathrm{ha}{ }^{-1}$ followed by CSP NPK scenarios with CSP of $0.92 \mathrm{MgC} \mathrm{ha}^{-1}$, respectively. Carbon sequestration in CSP NPK scenario denoted that even without any organic matter application soils could sequester organic carbon through balanced application of NPK. But application of FYM along with inorganic fertilizer led to an additional buildup of SOC in soil. Average rate of sequestration was 0.28 $\mathrm{MgC} \mathrm{ha}{ }^{-1} \mathrm{yr}^{-1}$ in the NPK+FYM treatment whereas in the NPK treatment the rate was $0.13 \mathrm{MgC} \mathrm{ha}{ }^{-1} \mathrm{yr}^{-1}$. Ghimire et al., (2012) revealed that $9.89 \%$ greater SOC in $0-50 \mathrm{~cm}$ soil profile under no-tillage than under conventional tillage in a rice-wheat system. The significant fraction of SOC under notillage was accumulated in surface soil with $28.3 \%$ greater SOC content in $0-5 \mathrm{~cm}$ depth of no-tillage system than that in the conventional tillage system.

Pandey et al., (2014) revealed that no-tillage before sowing of rice and wheat could increase SOC by $0.59 \mathrm{Mg} \mathrm{C} \mathrm{ha}^{-1} \mathrm{yr}^{-1}$. The rate of SOC sequestration due to reduced- or notillage management in rice-based systems in South Asia varied from 0- to $2114 \mathrm{~kg} \mathrm{ha}^{-1} \mathrm{yr}^{-1}$ (Bhattacharyya et al., 2012a).

The $\mathrm{C}$ sequestration rate was lowest $0.09 \%$ in the $\mathrm{F}_{1}$ control NPK treatment whereas it was highest in $\mathrm{F}_{6}\left(0.33 \mathrm{MgC} \mathrm{ha} \mathrm{yr}^{-1}\right)$ in the $\mathrm{NPK}+\mathrm{FYM}$ treatment. This shows that balanced fertilization helps in sequestering higher carbon than that sequestered by unbalanced fertilization. 
Table.1 Physicochemical properties and fertility status of the experimental soil before commencing the study

\begin{tabular}{|c|c|c|c|}
\hline \multirow[t]{2}{*}{ Soil characteristics } & \multicolumn{2}{|c|}{ Soil depth } & \multirow[t]{2}{*}{ Method followed } \\
\hline & $0-15 \mathrm{~cm}$ & $15-30 \mathrm{~cm}$ & \\
\hline \multicolumn{4}{|l|}{ Mechanical composition } \\
\hline Sand $(\%)$ & 56.5 & 56.4 & \multirow[t]{3}{*}{ Bouyoucos (1962) } \\
\hline Silt $(\%)$ & 25.0 & 26.0 & \\
\hline Clay $(\%)$ & 18.5 & 17.6 & \\
\hline Texture & Sandy loam & Sandy loam & \\
\hline pH & 8.44 & $8.44)$ & Jackson (1973) \\
\hline $\mathrm{EC}\left(\mathrm{dS} \mathrm{m^{-1 }}\right)$ & 0.32 & 0.25 & Jackson (1973) \\
\hline Bulk density $\left(\mathrm{Mg} \mathrm{m}^{-3}\right)$ & 1.59 & 1.72 & Veihmeyer and Hendrickson (1948)) \\
\hline Organic carbon $\left(\mathrm{g} \mathrm{kg}^{-1}\right)$ & 5.2 & 2.6 & Walkley and Black (1934) \\
\hline $\begin{array}{l}\mathrm{CEC}\left[\mathrm{cmol}\left(\mathrm{p}^{+}\right) \mathrm{kg}^{-1}\right. \\
\text { soil] })\end{array}$ & 10.76 & 6.15 & Jackson (1973) \\
\hline $\mathrm{KMnO}_{4}-\mathrm{N}\left(\mathrm{kg} \mathrm{ha}^{-1}\right)$ & 183.2 & 6.15 & Subbiah and Asija (1956) \\
\hline Olsen-P $\left(\mathrm{kg} \mathrm{ha}^{-1}\right)$ & 22.4 & 6.3 & Olsen et al., (1954) \\
\hline $\mathrm{NH}_{4} \mathrm{OAc}-\mathrm{K}\left(\mathrm{kg} \mathrm{ha}^{-1}\right)$ & 188 & 134 & Hanway and Heidel (1952) \\
\hline $\mathrm{CaCl}_{2}-\mathrm{S}\left(\mathrm{kg} \mathrm{ha}^{-1}\right)$ & 10.6 & 8.2 & Williams and Steinbergs (1959) \\
\hline
\end{tabular}

Table.2 Changes in grain yield, SOC pool on depth and mass basis in soil after 18 yrs of tillage crop residue practices and nutrient management practices

\begin{tabular}{|c|c|c|c|c|c|c|}
\hline \multirow[t]{2}{*}{ Treatments } & \multicolumn{2}{|c|}{$\begin{array}{c}\text { Mean grain } \\
\text { yield } \mathrm{t} \mathrm{ha}^{-1}\end{array}$} & \multicolumn{2}{|c|}{$\begin{array}{l}\text { Sustainable yield } \\
\text { index (SYI) }\end{array}$} & \multirow{2}{*}{$\begin{array}{l}\text { SOC pool }(0-30 \\
\text { cm) }\left(\mathrm{Mg} \mathrm{ha}^{-1}\right) \\
\text { equivalent depth } \\
\text { basis }\end{array}$} & \multirow{2}{*}{$\begin{array}{c}\text { SOC pool }(0-30 \\
\text { cm) }\left(M^{-1} \text { Mha }^{-1}\right) \\
\text { equivalent mass } \\
\text { basis }\end{array}$} \\
\hline & Rice & Wheat & Rice & Wheat & & \\
\hline \multicolumn{7}{|c|}{ Tillage crop residue practices } \\
\hline$T_{1}$ & $4.35^{\mathrm{c}}$ & $4.30^{\mathrm{de}}$ & $4.65^{\mathrm{cd}}$ & $4.35^{\mathrm{cd}}$ & $24.80^{\mathrm{d}}$ & $26.18^{\mathrm{d}}$ \\
\hline $\mathbf{T}_{2}$ & $4.71^{\mathrm{bc}}$ & $4.55^{\mathrm{cd}}$ & $4.95^{\mathrm{c}}$ & $4.80^{\mathrm{bc}}$ & $30.76^{\mathrm{bc}}$ & $30.87^{\mathrm{bc}}$ \\
\hline $\mathbf{T}_{3}$ & $5.35^{\mathrm{a}}$ & $5.15^{\mathrm{ab}}$ & $5.65^{\mathrm{ab}}$ & $5.35^{\mathrm{a}}$ & $36.23^{\mathrm{a}}$ & $34.30^{\mathrm{a}}$ \\
\hline $\mathbf{T}_{4}$ & $4.31^{\mathrm{c}}$ & $4.15^{\mathrm{ef}}$ & $4.45^{\mathrm{d}}$ & $4.25^{\mathrm{d}}$ & $24.15^{\mathrm{d}}$ & 24.96 \\
\hline $\mathbf{T}_{5}$ & $4.39^{c}$ & $4.90^{\mathrm{b}}$ & $4.70^{\text {cd }}$ & $5.10^{\mathrm{ab}}$ & $29.54^{\mathrm{bc}}$ & $28.85^{\mathrm{cd}}$ \\
\hline$T_{6}$ & $5.14^{\mathrm{ab}}$ & $5.45^{\mathrm{a}}$ & $5.25^{\mathrm{abc}}$ & $5.60^{\mathrm{a}}$ & $32.81^{\mathrm{ab}}$ & $31.69^{\mathrm{ab}}$ \\
\hline $\mathbf{T}_{7}$ & $5.75^{\mathrm{a}}$ & $3.90^{\mathrm{f}}$ & $5.90^{\mathrm{a}}$ & $4.05^{\mathrm{d}}$ & $24.23^{\mathrm{d}}$ & $23.26^{\mathrm{e}}$ \\
\hline \multicolumn{7}{|c|}{ Nutrient Management Practices } \\
\hline $\mathbf{F}_{1}$ & $2.72^{\mathrm{e}}$ & $2.32^{\mathrm{e}}$ & $3.3^{\mathrm{d}}$ & $3.1^{\mathrm{e}}$ & $11.35^{\mathrm{e}}$ & $10.67^{\mathrm{e}}$ \\
\hline$F_{2}$ & $3.10^{\mathrm{de}}$ & $2.81^{\mathrm{d}}$ & $3.5^{\mathrm{d}}$ & $3.4^{\mathrm{d}}$ & $24.96^{\mathrm{d}}$ & $25.31^{\mathrm{d}}$ \\
\hline$F_{3}$ & $4.66^{\mathrm{bc}}$ & $4.83^{c}$ & $4.7^{\mathrm{c}}$ & $4.9^{c}$ & $25.26^{\text {cd }}$ & $26.16^{\mathrm{cd}}$ \\
\hline$F_{4}$ & $4.86^{\mathrm{b}}$ & $5.33^{\mathrm{abc}}$ & $5.7^{\mathrm{ab}}$ & $5.9^{\mathrm{a}}$ & $35.24^{\mathrm{ab}}$ & $34.02^{\mathrm{ab}}$ \\
\hline$F_{5}$ & $4.90^{\mathrm{ab}}$ & $5.40^{\mathrm{ab}}$ & $5.5^{\mathrm{b}}$ & $5.2^{\mathrm{b}}$ & $33.59^{\mathrm{abc}}$ & $31.82^{\mathrm{abc}}$ \\
\hline$F_{6}$ & $5.58^{\mathrm{a}}$ & $5.75^{\mathrm{a}}$ & $6.2^{\mathrm{a}}$ & $6.1^{\mathrm{a}}$ & $36.09^{\mathrm{a}}$ & $35.28^{\mathrm{a}}$ \\
\hline$F_{7}$ & $4.10^{c}$ & $4.33^{c}$ & $4.9^{c}$ & $4.7^{\mathrm{c}}$ & $23.82^{d}$ & $23.69^{d}$ \\
\hline
\end{tabular}

** Different letters within columns are significantly different at $\mathrm{P}=0.05$ according to Duncan Multiple Range Test (DMRT) for separation of means. 
Table.3 Concentrations of different soil organic matter carbon fractions ${ }_{\mathrm{c}} \mathrm{POM}$ and ${ }_{\mathrm{f}} \mathrm{POM}$ at different soil depths as affected by tillage and nutrient management to the continuous RW

cropping system

\begin{tabular}{|c|c|c|c|c|c|c|c|c|c|c|}
\hline \multirow[t]{2}{*}{ Treatments } & \multicolumn{5}{|c|}{ 0-15 cm layer } & \multicolumn{5}{|c|}{$15-30 \mathrm{~cm}$ layer } \\
\hline & $\begin{array}{l}\text { WSC } \\
\left(\mathrm{mgkg}^{-1}\right)\end{array}$ & $\begin{array}{l}\mathrm{MBC} \\
\left(\mathrm{mgkg}^{-1}\right)\end{array}$ & $\begin{array}{l}\mathrm{LFC} \\
\left(\mathrm{mgkg}^{-1}\right)\end{array}$ & $\begin{array}{l}\text { cPOM-C } \\
\left(\mathrm{g} \mathrm{C} \mathrm{kg}^{-1} \text { soil) }\right.\end{array}$ & $\begin{array}{l}\mathrm{f} P O M-C \\
\left(\mathrm{~g} \mathrm{C} \mathrm{kg}^{-1} \text { soil) }\right.\end{array}$ & $\begin{array}{l}\text { WSC } \\
\left(\mathrm{mgkg}^{-1}\right)\end{array}$ & $\begin{array}{l}\mathrm{MBC} \\
\left(\mathrm{mgkg}^{-1}\right)\end{array}$ & $\begin{array}{l}\mathrm{LFC} \\
\left(\mathrm{mgkg}^{-1}\right)\end{array}$ & $\begin{array}{l}\text { cPOM-C } \\
\left(\mathrm{g} \mathrm{C} \mathrm{kg}^{-1} \text { soil }\right)\end{array}$ & $\begin{array}{l}{ }_{\mathrm{f}} \mathrm{POM}-\mathrm{C} \\
\left(\mathrm{g} \mathrm{C} \mathrm{kg}^{-1} \text { soil }\right)\end{array}$ \\
\hline \multicolumn{11}{|c|}{ Tillage crop residue practices } \\
\hline$T_{1}$ & $23.9^{\mathrm{d}}$ & $311.4^{\mathrm{c}}$ & $81.3^{\mathrm{d}}$ & $0.44^{\mathrm{d}}$ & $1.22^{\mathrm{cd}}$ & $15.7^{\mathrm{d}}$ & $193.9^{\text {cd }}$ & $65.1^{\mathrm{d}}$ & $0.32^{\text {cd }}$ & $1.05^{\mathrm{bc}}$ \\
\hline$T_{2}$ & $25.9^{c}$ & $345.2^{\mathrm{bc}}$ & $107.8^{\mathrm{bc}}$ & $0.62^{\mathrm{bcd}}$ & $1.82^{\mathrm{bc}}$ & $17.8^{\mathrm{cd}}$ & $219.8^{\mathrm{c}}$ & $94.1^{\mathrm{bc}}$ & $0.25^{\mathrm{de}}$ & $0.81^{\mathrm{bcd}}$ \\
\hline $\mathbf{T}_{3}$ & $27.8^{\mathrm{ab}}$ & $481.7^{\mathrm{a}}$ & $155.2^{\mathrm{a}}$ & $0.86^{\mathrm{bc}}$ & $2.54^{\mathrm{a}}$ & $19.6^{\mathrm{bc}}$ & $294.8^{\mathrm{ab}}$ & $132.6^{\mathrm{a}}$ & $0.33^{\mathrm{c}}$ & $1.93^{\mathrm{a}}$ \\
\hline$T_{4}$ & $22.7^{\mathrm{d}}$ & $306.5^{\mathrm{c}}$ & $95.7^{\mathrm{c}}$ & $0.94^{\mathrm{ab}}$ & $2.21^{\mathrm{ab}}$ & $17.6^{\mathrm{cd}}$ & $187.5^{\mathrm{cd}}$ & $87.6^{\mathrm{c}}$ & $0.35^{\mathrm{bc}}$ & $1.34^{\mathrm{ab}}$ \\
\hline $\mathbf{T}_{5}$ & $26.4^{\mathrm{bc}}$ & $398.6^{\mathrm{b}}$ & $128.8^{\mathrm{b}}$ & $1.30^{\mathrm{a}}$ & $2.38^{\mathrm{ab}}$ & $20.3^{\mathrm{ab}}$ & $240.9^{\mathrm{bc}}$ & $102.9^{\mathrm{b}}$ & $0.92 \mathrm{a}$ & $1.64^{\mathrm{a}}$ \\
\hline$T_{6}$ & $29.2^{\mathrm{a}}$ & $535.8^{\mathrm{a}}$ & $177.8^{\mathrm{a}}$ & $0.53^{\text {cd }}$ & $1.03^{\mathrm{d}}$ & $22.6^{\mathrm{a}}$ & $361.8^{\mathrm{a}}$ & $141.2^{\mathrm{a}}$ & $0.21^{\mathrm{e}}$ & $0.49^{\mathrm{cd}}$ \\
\hline $\mathbf{T}_{7}$ & $17.2^{\mathrm{e}}$ & $266.7^{\mathrm{c}}$ & $52.7^{\mathrm{e}}$ & $0.38^{\mathrm{d}}$ & $0.94^{\mathrm{d}}$ & $13.2^{\mathrm{e}}$ & $145.9^{\mathrm{d}}$ & $49.8^{\mathrm{e}}$ & $0.16^{\mathrm{t}}$ & $0.41^{\mathrm{d}}$ \\
\hline \multicolumn{11}{|c|}{ Nutrient Management Practices } \\
\hline $\mathbf{F}_{1}$ & $21.9^{\mathrm{e}}$ & $116.8^{\mathrm{c}}$ & $89.2^{\mathrm{c}}$ & $0.41^{\mathrm{d}}$ & $0.64^{\mathrm{d}}$ & $15.1^{\mathrm{e}}$ & $106.6^{\mathrm{d}}$ & $47.9^{\mathrm{f}}$ & 0.18 & $0.48^{\mathrm{d}}$ \\
\hline $\mathbf{F}_{2}$ & $29.2^{\mathrm{cd}}$ & $239.9^{\mathrm{bc}}$ & $96.4^{\mathrm{c}}$ & $0.61^{\mathrm{cd}}$ & $0.93^{\mathrm{d}}$ & $20.2^{\mathrm{cd}}$ & $196.8^{\mathrm{bc}}$ & $85.9^{\mathrm{d}}$ & 0.24 & $0.65^{\mathrm{cd}}$ \\
\hline $\mathbf{F}_{3}$ & $29.8^{\mathrm{c}}$ & $280.7 b$ & $123.5 b$ & $1.33^{\mathrm{ab}}$ & $2.81^{\mathrm{ab}}$ & $21.9^{\mathrm{bc}}$ & $219.9^{\mathrm{bc}}$ & $103.2^{\mathrm{bc}}$ & 0.72 & $1.64^{\mathrm{ab}}$ \\
\hline $\mathbf{F}_{4}$ & $28.4^{\mathrm{d}}$ & $189.2^{\mathrm{c}}$ & $91.3^{\mathrm{c}}$ & $0.50^{\text {cd }}$ & $1.52^{\mathrm{cd}}$ & $18.8^{\mathrm{d}}$ & $166.8^{\mathrm{cd}}$ & $66.7^{\mathrm{e}}$ & 0.25 & 0.74 \\
\hline$F_{5}$ & $32.5^{\mathrm{a}}$ & $424.1^{\mathrm{a}}$ & $183.9^{\mathrm{a}}$ & $1.89^{\mathrm{a}}$ & $3.78^{\mathrm{a}}$ & $26.4^{\mathrm{a}}$ & $324.9^{\mathrm{a}}$ & $152.9^{\mathrm{a}}$ & 0.92 & $2.34^{\mathrm{a}}$ \\
\hline$F_{6}$ & $31.6^{\mathrm{ab}}$ & $343.9^{\mathrm{ab}}$ & $160.5^{\mathrm{a}}$ & $1.05^{\mathrm{bc}}$ & $1.84^{\mathrm{bc}}$ & $23.6^{\mathrm{ab}}$ & $267.3^{\mathrm{a}}$ & $139.7^{\mathrm{a}}$ & 0.30 & $1.38^{\mathrm{b}}$ \\
\hline $\mathbf{F}_{7}$ & $30.9^{b}$ & $341.7^{b}$ & $108.1^{\mathrm{bc}}$ & $0.62^{\text {cd }}$ & $2.13^{\mathrm{bc}}$ & $22.7^{\mathrm{b}}$ & $260.3^{\mathrm{b}}$ & $96.9^{\text {cd }}$ & 0.68 & $1.33^{\mathrm{bc}}$ \\
\hline
\end{tabular}

** Different letters within columns are significantly different at $\mathrm{P}=0.05$ according to Duncan Multiple Range Test $($ DMRT) for separation of means. WSC $=$ water soluble carbon, $\mathrm{MBC}=$ microbial biomass carbon, $\mathrm{LFC}=$ labile fraction carbon, ${ }_{c} \mathrm{POM}=$ coarse particulate organic carbon, ${ }_{\mathrm{f}} \mathrm{POM}=$ fine particulate organic carbon

Table.4 Changes in soil organic carbon (SOC) $\left(\mathrm{g} \mathrm{kg}^{-1}\right)$ concentration in soil after 18 yr of tillage crop residue practices and nutrient management practices ( \pm standard deviation from mean)

At the end of experiment (in 2018)

\begin{tabular}{|c|c|c|c|c|c|c|c|c|c|}
\hline $\begin{array}{l}\text { Soil } \\
\text { Depth } \\
\text { (cm) }\end{array}$ & $\begin{array}{l}\text { Initial } \\
(2000)\end{array}$ & $\begin{array}{l}F_{1} \\
\text { Control }\end{array}$ & $\begin{array}{l}\mathbf{F}_{2^{-}} \\
\mathbf{5 0 \%} \mathbf{R D N}\end{array}$ & $\begin{array}{l}\mathrm{F}_{3^{-}} \\
100 \% \text { RDN }\end{array}$ & $\begin{array}{l}\mathbf{F}_{4^{-}} \\
100 \% \text { organic } \\
\text { (FYM) }\end{array}$ & $\begin{array}{l}\mathrm{F}_{5^{-}} \\
\mathbf{5 0 \%} \mathrm{RDN} \\
+\mathbf{5 0 \%} \text { foliar }\end{array}$ & $\begin{array}{l}\mathbf{F}_{6^{-}} \\
\mathbf{5 0 \%} \text { organic } \\
\text { (FYM)+50\% RDN }\end{array}$ & $\begin{array}{l}\text { F }_{7^{-}} \\
\text {Farmers } \\
\text { practice }\end{array}$ & Mean \\
\hline $0-15$ & $4.7 \pm 0.26$ & $3.7 \pm 0.19^{\mathrm{Db}}$ & $3.9 \pm 0.18^{\mathrm{Db}}$ & $5.1 \pm 0.21^{\mathrm{Ab}}$ & $5.4 \pm 0.26^{\mathrm{Ba}}$ & $4.9 \pm 0.23^{\mathrm{Ca}}$ & $5.8 \pm 0.28^{\mathrm{Aa}}$ & $4.8 \pm 0.23^{\mathrm{Cb}}$ & $4.8 \pm 0.23^{\mathrm{Cb}}$ \\
\hline $15-30$ & $4.5 \pm 0.25$ & $3.1 \pm 0.18^{\mathrm{Cc}}$ & $3.2 \pm 0.17^{\mathrm{Ca}}$ & $4.6 \pm 0.19^{\mathrm{cb}}$ & $5.2 \pm 0.22^{\mathrm{Ba}}$ & $4.1 \pm 0.21^{\mathrm{Cb}}$ & $5.5 \pm 0.23^{\mathrm{Aa}}$ & $3.3 \pm 0.18^{\mathrm{Cc}}$ & $4.2 \pm 0.20^{\mathrm{Cc}}$ \\
\hline $30-60$ & $3.1 \pm 0.19$ & $2.1 \pm 0.13^{\mathrm{Cd}}$ & $2.4 \pm 0.13^{\mathrm{Fa}}$ & $3.3 \pm 0.18^{\mathrm{Cc}}$ & $4.5 \pm 0.19^{\mathrm{Bb}}$ & $3.1 \pm 0.18^{\mathrm{Cc}}$ & $5.1 \pm 0.21^{\mathrm{Ab}}$ & $2.8 \pm 0.15^{\mathrm{Bc}}$ & $3.3 \pm 0.17^{\mathrm{Cc}}$ \\
\hline $60-80$ & $2.3 \pm 0.13$ & $1.1 \pm 0.07^{\mathrm{cb}}$ & $1.9 \pm 0.11^{\mathrm{Aa}}$ & $2.8 \pm 015^{\mathrm{cd}}$ & $2.7 \pm 0.15^{\mathrm{ca}}$ & $2.3 \pm 0.14^{\mathrm{Ea}}$ & $3.4 \pm 0.19^{\mathrm{Ac}}$ & $1.9 \pm 0.11^{\mathrm{Ca}}$ & $2.3 \pm 0.13^{\mathrm{Ca}}$ \\
\hline $80-100$ & $1.4 \pm 0.09$ & $0.9 \pm 0.05^{\mathrm{Cc}}$ & $1.1 \pm 0.07^{\mathrm{Db}}$ & $1.6 \pm 0.10^{\mathrm{Ab}}$ & $1.9 \pm 0.12^{\mathrm{Cb}}$ & $1.5 \pm 0.09^{\mathrm{Bb}}$ & $2.3 \pm 0.13^{\mathrm{Ad}}$ & $1.2 \pm 0.07^{\mathrm{Cb}}$ & $1.5 \pm 0.09^{\mathrm{Bb}}$ \\
\hline Mean & $3.2 \pm 0.18$ & $2.2 \pm 0.12^{\mathrm{Cc}}$ & $2.5 \pm 0.13^{\mathrm{Db}}$ & $3.5 \pm 0.18^{\mathrm{Cb}}$ & $3.9 \pm 0.19^{\mathrm{Bb}}$ & $3.2 \pm 0.17^{\mathrm{Cc}}$ & $4.4 \pm 0.21 \mathrm{Aa}$ & $2.8 \pm 015^{\mathrm{Bc}}$ & - \\
\hline
\end{tabular}

** Different letters within columns are significantly different at $\mathrm{P}=0.05$ according to Duncan Multiple Range Test (DMRT) for separation of means.

Table.5 Profile soil organic carbon (SOC) as affected by $18 \mathrm{yr}$ of tillage crop residue practices and nutrient management practices

\begin{tabular}{|c|c|c|c|c|c|c|c|c|c|}
\hline \multirow{4}{*}{$\begin{array}{l}\text { Tillage crop } \\
\text { residue } \\
\text { practices }\end{array}$} & \multirow{4}{*}{$\begin{array}{l}\text { Initial } \\
\text { SOC stock }\end{array}$} & \multicolumn{8}{|c|}{2018} \\
\hline & & \multicolumn{8}{|c|}{$\mathrm{Mg} \mathrm{Cha}^{-1}$} \\
\hline & & \multicolumn{8}{|c|}{ Fertilization } \\
\hline & & $\mathbf{F}_{1} * *$ & $\mathbf{F}_{2}$ & $\mathbf{F}_{3}$ & $\mathbf{F}_{4}$ & $\mathbf{F}_{5}$ & $F_{6}$ & $\mathbf{F}_{7}$ & Mean \\
\hline$T_{1}$ & $20.9 \pm 1.6$ & $19.2 \pm 1.3^{\mathrm{D \dagger}}$ & $26.9 \pm 1.6^{\mathrm{D}}$ & $54.1 \pm 1.7^{\mathrm{D}}$ & $63.3+2.8^{\mathrm{C}}$ & $36.9 \pm 1.5^{\mathrm{C}}$ & $70.5 \pm 3.7^{\mathrm{D}}$ & $35.1 \pm 1.7^{\mathrm{D}}$ & $43.7 \pm 2.0^{\mathrm{D}}$ \\
\hline $\mathbf{T}_{2}$ & & $23.0 \pm 1.7^{\mathrm{B}}$ & $33.5+2.5^{\mathrm{D}}$ & $65.8 \pm 2.0^{\mathrm{B}}$ & $70.9+3.7^{\mathrm{A}}$ & $44.9 \pm 1.9^{B}$ & $81.6 \pm 4.2^{\mathrm{B}}$ & $39.8 \pm 1.3^{\mathrm{D}}$ & $51.4 \pm 2.5^{\mathrm{B}}$ \\
\hline $\mathbf{T}_{3}$ & & $16.7 \pm 1.3^{\mathrm{D}}$ & $23.4 \pm 1.9^{B}$ & $52.0 \pm 1.6^{\mathrm{D}}$ & $58.6 \pm 1.6^{\mathrm{D}}$ & $33.2 \pm 1.5^{\mathrm{C}}$ & $63.5 \pm 3.3^{\mathrm{E}}$ & $31.3 \pm 0.1^{\mathrm{B}}$ & $39.9 \pm 1.6^{\mathrm{D}}$ \\
\hline $\mathbf{T}_{4}$ & & $20.5 \pm 1.5^{C}$ & $30.7 \pm 2.4^{B}$ & $62.6 \pm 1.9^{C}$ & $69.4+3.3^{\mathrm{B}}$ & $39.7 \pm 1.3^{B}$ & $79.1 \pm 4.1^{\mathrm{C}}$ & $36.7 \pm 1.5^{C}$ & $48.4 \pm 2.3^{\mathrm{C}}$ \\
\hline $\mathbf{T}_{5}$ & & $18.0 \pm 1.3^{\mathrm{D}}$ & $25.5 \pm 2.1^{\mathrm{A}}$ & $53.4 \pm 1.7^{\mathrm{D}}$ & $61.3 \pm 2.1^{\mathrm{A}}$ & $34.4 \pm 1.3^{\mathrm{D}}$ & $67.0 \pm 1.4^{\mathrm{B}}$ & $32.1 \pm 0.1^{\mathrm{B}}$ & $41.7 \pm 1.4^{\mathrm{D}}$ \\
\hline $\mathrm{T}_{6}$ & & $26.5 \pm 1.9^{\mathrm{A}}$ & $42.5 \pm 3.1^{\mathrm{A}}$ & $68.5 \pm 2.1^{\mathrm{A}}$ & $73.0+3.6^{\mathrm{A}}$ & $49.7 \pm 1.8^{C}$ & $85.7 \pm 4.5^{\mathrm{A}}$ & $48.2 \pm 2.1^{\mathrm{A}}$ & $56.3 \pm 2.7^{\mathrm{A}}$ \\
\hline $\mathbf{T}_{7}$ & & $15.8 \pm 1.2^{\mathrm{E}}$ & $19.3 \pm 1.8^{\mathrm{C}}$ & $49.0 \pm 1.5^{\mathrm{E}}$ & $51.7+2.5^{\mathrm{D}}$ & $29.8 \pm 1.2^{\mathrm{E}}$ & $58.0 \pm 1.3^{\mathrm{C}}$ & $27.4 \pm 1.7^{\mathrm{D}}$ & $28.7 \pm 1.6^{\mathrm{E}}$ \\
\hline Mean & & $19.9 \pm 1.5^{\mathrm{D}}$ & $28.8 \pm 2.2^{\mathrm{B}}$ & $57.9 \pm 1.8^{\mathrm{D}}$ & $64.0 \pm 2.8^{\mathrm{C}}$ & $38.4 \pm 1.5^{\mathrm{C}}$ & $72.2 \pm 3.2^{\mathrm{C}}$ & $35.8 \pm 1.2^{\mathrm{D}}$ & - \\
\hline
\end{tabular}

** Different letters within columns are significantly different at $\mathrm{P}=0.05$ according to Duncan Multiple Range Test (DMRT) for separation of means. 
Table.6 C restoration rate in soil profile as affected by $18 \mathrm{yr}$ of tillage crop residue practices and nutrient management practices

\begin{tabular}{|c|c|c|c|c|c|c|c|c|}
\hline \multirow{4}{*}{$\begin{array}{l}\text { Tillage crop } \\
\text { residue practices }\end{array}$} & \multicolumn{8}{|c|}{ Ä SOC Stock in $18 \mathrm{yr}$} \\
\hline & \multicolumn{8}{|c|}{ Total per cent } \\
\hline & \multicolumn{8}{|c|}{ Fertilization } \\
\hline & $\mathbf{F}_{1} * *$ & $\mathbf{F}_{2}$ & $\mathbf{F}_{3}$ & $\mathbf{F}_{4}$ & $\mathbf{F}_{5}$ & $\mathbf{F}_{6}$ & $\mathbf{F}_{7}$ & Mean \\
\hline $\mathrm{T}_{1}$ & $10.16^{\mathrm{d}}$ & $20.44^{\mathrm{a}}$ & $36.64^{\mathrm{a}}$ & $46.07^{\mathrm{a}}$ & $30.80^{\mathrm{a}}$ & $52.19^{\mathrm{a}}$ & $17.78^{\mathrm{a}}$ & $30.58^{\mathrm{a}}$ \\
\hline $\mathbf{T}_{2}$ & $12.48^{\mathrm{ab}}$ & $24.66^{\mathrm{c}}$ & $38.28^{\mathrm{c}}$ & $51.61^{\mathrm{a}}$ & $33.11^{\mathrm{a}}$ & $54.02^{\mathrm{a}}$ & $18.69^{\mathrm{a}}$ & $33.26^{\mathrm{a}}$ \\
\hline $\mathbf{T}_{3}$ & $6.86^{\mathrm{d}}$ & $18.94^{\mathrm{a}}$ & $34.79^{\mathrm{a}}$ & $41.01^{\mathrm{ab}}$ & $26.23^{b c}$ & $49.58^{\mathrm{a}}$ & $13.72^{\mathrm{a}}$ & $27.30^{\mathrm{bc}}$ \\
\hline $\mathbf{T}_{4}$ & $12.14^{b}$ & $21.65^{\mathrm{a}}$ & $38.17^{\mathrm{c}}$ & $47.96^{\mathrm{a}}$ & $31.37^{\mathrm{a}}$ & $53.35^{\mathrm{a}}$ & $18.43^{\mathrm{a}}$ & $31.87^{\mathrm{a}}$ \\
\hline $\mathbf{T}_{5}$ & $8.16^{d}$ & $19.75^{a}$ & $35.25^{b}$ & $42.69^{a}$ & $28.36^{\mathrm{a}}$ & $51.91^{\mathrm{a}}$ & $15.31^{\mathrm{c}}$ & $28.35^{b}$ \\
\hline $\mathrm{T}_{6}$ & $13.46 \mathrm{a}^{\mathrm{b}}$ & $26.89^{\mathrm{ab}}$ & $47.43^{\mathrm{a}}$ & $53.44^{\mathrm{a}}$ & $34.49^{\mathrm{a}}$ & $55.39^{a}$ & $18.73^{\mathrm{a}}$ & $35.69^{a}$ \\
\hline $\mathbf{T}_{7}$ & $5.24^{\mathrm{e}}$ & $17.17^{\mathrm{a}}$ & $32.03^{a}$ & $12.67^{\mathrm{ab}}$ & $25.16^{\mathrm{bc}}$ & $39.98^{b c}$ & $12.67^{\mathrm{ab}}$ & $24.27^{b c}$ \\
\hline Mean & $9.79^{d}$ & $21.36^{\mathrm{a}}$ & $37.51^{\mathrm{c}}$ & $45.78^{\mathrm{a}}$ & $29.93^{\mathrm{a}}$ & $50.63^{\mathrm{a}}$ & $16.48^{\mathrm{a}}$ & - \\
\hline
\end{tabular}

** Different letters within columns are significantly different at $\mathrm{P}=0.05$ according to Duncan Multiple Range

Test (DMRT) for separation of means.

Table.7 Carbon budget and sequestration in soil profile as affected by 18 yr of tillage crop residue practices and nutrient management practices

\begin{tabular}{|c|c|c|c|c|c|c|}
\hline \multirow[t]{2}{*}{ Treatments } & \multicolumn{2}{|c|}{$\begin{array}{c}\text { C sequestration potential (Mg C } \\
\text { ha }^{-1} \text { ) }\end{array}$} & \multicolumn{2}{|c|}{$\begin{array}{c}\text { Rate of C sequestration ( } \mathrm{Mg} \mathrm{C} \mathrm{ha}^{-1} \\
\left.\mathrm{yr}^{-1}\right)\end{array}$} & \multicolumn{2}{|c|}{ C sequestration efficiency (\%) } \\
\hline & CSP- NPK ${ }^{a}$ & CSP- FYM ${ }^{b}$ & CSP- NPK ${ }^{a}$ & CSP FYM $^{b}$ & CSP- NPK ${ }^{\mathrm{a}}$ & CSP- FYM $^{b}$ \\
\hline \multicolumn{7}{|c|}{ Tillage crop residue practices } \\
\hline $\mathrm{T}_{1}$ & $1.15^{\mathrm{d}}$ & $2.53^{\mathrm{d}}$ & $0.32 c^{d}$ & $0.39^{\mathrm{e}}$ & $6.53^{\mathrm{cd}}$ & $9.20^{\mathrm{d}}$ \\
\hline $\mathbf{T}_{2}$ & $2.93^{\mathrm{ab}}$ & $6.93^{\mathrm{ab}}$ & $0.46^{\mathrm{bc}}$ & $0.57^{\mathrm{bc}}$ & $11.51^{\mathrm{bc}}$ & $28.43^{\mathrm{ab}}$ \\
\hline $\mathbf{T}_{3}$ & $3.05^{\mathrm{a}}$ & $9.76^{\mathrm{a}}$ & $0.78^{\mathrm{a}}$ & $1.19^{\mathrm{a}}$ & $19.46^{\mathrm{a}}$ & $35.81 \mathrm{a}$ \\
\hline$T_{4}$ & $1.39^{\mathrm{cd}}$ & 2.09 & $0.31^{\mathrm{d}}$ & $0.44 \mathrm{de}$ & $4.29^{\mathrm{de}}$ & $7.24^{\mathrm{de}}$ \\
\hline $\mathbf{T}_{5}$ & $2.30^{\mathrm{bc}}$ & $4.77^{\mathrm{c}}$ & $0.39^{\mathrm{cd}}$ & $0.54^{\mathrm{cd}}$ & $8.29^{\mathrm{bc}}$ & $18.10^{\mathrm{c}}$ \\
\hline$T_{6}$ & $2.75^{\mathrm{ab}}$ & $4.83^{\mathrm{bc}}$ & $0.63^{\mathrm{ab}}$ & $0.82^{\mathrm{ab}}$ & $13.34^{\mathrm{ab}}$ & $27.16^{\mathrm{b}}$ \\
\hline $\mathbf{T}_{7}$ & $0.84^{\mathrm{e}}$ & $0.67^{\mathrm{e}}$ & $0.26^{\mathrm{e}}$ & $0.36^{\mathrm{e}}$ & $2.24^{\mathrm{e}}$ & $3.43^{\mathrm{e}}$ \\
\hline \multicolumn{7}{|c|}{ Nutrient Management Practices } \\
\hline$F_{1}$ & $0.43^{\mathrm{e}}$ & $0.87^{\mathrm{e}}$ & $0.06^{\mathrm{d}}$ & $0.12^{\mathrm{e}}$ & $0.39^{\mathrm{d}}$ & $1.28^{\mathrm{d}}$ \\
\hline$F_{2}$ & $1.46^{\mathrm{d}}$ & $1.87^{\mathrm{cd}}$ & $0.11^{\mathrm{c}}$ & $0.19^{\text {de }}$ & $1.48^{\mathrm{cd}}$ & $2.13^{\mathrm{cd}}$ \\
\hline$F_{3}$ & $1.88^{\mathrm{c}}$ & $3.03^{b c}$ & $0.14 \mathrm{a}^{\mathrm{b}}$ & $0.29^{\mathrm{bc}}$ & $3.16^{\mathrm{bc}}$ & $6.18^{b c}$ \\
\hline$F_{4}$ & $2.93^{\mathrm{a}}$ & $3.89^{\mathrm{b}}$ & $0.16^{\mathrm{a}}$ & $0.37^{\mathrm{ab}}$ & $8.82^{\mathrm{a}}$ & $10.23^{\mathrm{ab}}$ \\
\hline$F_{5}$ & $2.62^{\mathrm{ab}}$ & $3.33^{\mathrm{b}}$ & $0.15^{\mathrm{ab}}$ & $0.31^{\mathrm{b}}$ & $4.40^{\mathrm{b}}$ & $7.97^{\mathrm{bc}}$ \\
\hline$F_{6}$ & $3.17^{\mathrm{a}}$ & $6.87^{\mathrm{a}}$ & $0.17^{\mathrm{a}}$ & $0.49 a$ & $9.78^{\mathrm{a}}$ & $16.37^{\mathrm{a}}$ \\
\hline $\mathbf{F}_{7}$ & $2.35^{\mathrm{bc}}$ & $3.01^{\mathrm{bc}}$ & $0.13^{\mathrm{bc}}$ & $0.22^{\mathrm{d}}$ & $3.98^{\mathrm{b}}$ & $5.46^{\mathrm{bc}}$ \\
\hline
\end{tabular}

** Different letters within columns are significantly different at $\mathrm{P}=0.05$ according to Duncan Multiple Range Test (DMRT) for separation of means.

Table.8 Change in nitrifying and denitrifying bacteria in soil profile as affected by $18 \mathrm{yr}$ of tillage crop residue practices and nutrient management practices

\begin{tabular}{|c|c|c|c|c|c|c|c|}
\hline $\begin{array}{c}\text { Tillage crop residue } \\
\text { practices }\end{array}$ & \multicolumn{3}{|c|}{ Nitrifying bacteria $\left(\times \mathbf{1 0}^{3} / \mathbf{g}\right)$} & \multicolumn{3}{c|}{ Denitrifying bacteria $\left(\times 10^{4} / \mathbf{g}\right)$} \\
\hline & $\begin{array}{c}\text { Jointing } \\
\text { stage }\end{array}$ & $\begin{array}{c}\text { Booting } \\
\text { stage }\end{array}$ & $\begin{array}{c}\text { Milky } \\
\text { stage }\end{array}$ & $\begin{array}{c}\text { Jointing } \\
\text { stage }\end{array}$ & $\begin{array}{c}\text { Booting } \\
\text { stage }\end{array}$ & $\begin{array}{c}\text { Milky } \\
\text { stage }\end{array}$ \\
\hline $\mathbf{T}_{\mathbf{1}}$ & $2.0 \pm 0.4^{\mathrm{c}}$ & $4.2 \pm 6.5^{\mathrm{a}}$ & $35.4 \pm 4.1^{\mathrm{c}}$ & $35.6 \pm 10.3^{\mathrm{cd}}$ & $42.0^{\mathrm{c}} \pm 8.5^{\mathrm{c}}$ & $59.7 \pm 5.3^{\mathrm{bc}}$ \\
\hline $\mathbf{T}_{\mathbf{2}}$ & $5.9 \pm 1.0^{\mathrm{b}}$ & $7.2 \pm 0.6^{\mathrm{c}}$ & $48.6 \pm 9.2^{\mathrm{bc}}$ & $41.2 \pm 8.8^{\mathrm{bc}^{\mathrm{c}}}$ & $63.8 \pm 10.7^{\mathrm{bc}}$ & $95.1 \pm 20.6^{\mathrm{b}}$ \\
\hline $\mathbf{T}_{3}$ & $6.5 \pm 0.7^{\mathrm{b}}$ & $13.9 \pm 1.3^{\mathrm{b}}$ & $64.3 \pm 6.2^{\mathrm{b}}$ & $69.3 \pm 6.6^{\mathrm{a}}$ & $110.8 \pm 10.7^{\mathrm{b}}$ & $137.1 \pm 9.9^{\mathrm{a}}$ \\
\hline $\mathbf{T}_{\mathbf{4}}$ & $3.9 \pm 1.4^{\mathrm{bc}}$ & $11.6 \pm 0.8^{\mathrm{bc}}$ & $48.2 \pm 8.2^{\mathrm{bc}}$ & $23.8 \pm 0.9^{\mathrm{d}}$ & $32.8 \pm 2.4^{\mathrm{d}}$ & $57.3 \pm 20.1^{\mathrm{a}}$ \\
\hline $\mathbf{T}_{5}$ & $9.9 \pm 0.7^{\mathrm{a}}$ & $19.6 \pm 1.0^{\mathrm{b}}$ & $107.8 \pm 4.1^{\mathrm{a}}$ & $34.5 \pm 5.7^{\mathrm{cd}}$ & $54.3 \pm 4.3^{\mathrm{cd}}$ & $82.2 \pm 11.6^{\mathrm{a}}$ \\
\hline $\mathbf{T}_{\mathbf{6}}$ & $10.1 \pm 1.7^{\mathrm{a}}$ & $19.9 \pm 0.8^{\mathrm{b}}$ & $119.3 \pm 8.4^{\mathrm{a}}$ & $60.9 \pm 3.9^{\mathrm{ab}}$ & $82.5 \pm 11.8^{\mathrm{b}}$ & $114.5 \pm 9.3^{\mathrm{a}}$ \\
\hline $\mathbf{T}_{7}$ & $1.80 \pm 0.6^{\mathrm{c}}$ & $3.9 \pm 0.7^{\mathrm{c}}$ & $29.8 \pm 3.4^{\mathrm{c}}$ & $17.6 \pm 2.4^{\mathrm{c}}$ & $23.8 \pm 3.9^{\mathrm{c}}$ & $28.7 \pm 4.1^{\mathrm{c}}$ \\
\hline
\end{tabular}

** Different letters within columns are significantly different at $\mathrm{P}=0.05$ according to Duncan Multiple Range Test (DMRT) for separation of means. 
Table.9 Effect of tillage crop residue practices and nutrient management practices on the soil enzymatic activities

\begin{tabular}{|c|c|c|c|c|c|c|c|c|c|}
\hline \multirow{2}{*}{$\begin{array}{l}\text { Tillage } \\
\text { crop } \\
\text { residue } \\
\text { practices }\end{array}$} & \multicolumn{3}{|c|}{ Nitrate reductase $\left[\mathrm{mg} \mathrm{NO}_{3}-\mathrm{N} /(\mathrm{g} 24\right.$ h)] } & \multicolumn{3}{|c|}{ Urease [mg / (kg 24 h)] } & \multicolumn{3}{|c|}{ Invertase [mg / (g 24 h)] } \\
\hline & $\begin{array}{l}\text { Jointing } \\
\text { stage }\end{array}$ & $\begin{array}{l}\text { Booting } \\
\text { stage }\end{array}$ & $\begin{array}{l}\text { Milky } \\
\text { stage }\end{array}$ & $\begin{array}{l}\text { Jointing } \\
\text { stage }\end{array}$ & $\begin{array}{l}\text { Booting } \\
\text { stage }\end{array}$ & $\begin{array}{l}\text { Milky } \\
\text { stage }\end{array}$ & Jointing stage & Booting stage & $\begin{array}{l}\text { Milky } \\
\text { stage }\end{array}$ \\
\hline $\mathrm{T}_{1}$ & $4.58 \pm 0.14$ & $4.23 \pm 0.66$ & $0.46 \pm 0.04$ & $4.08 \pm 1.84$ & $19.97 \pm 0.94$ & $16.82 \pm 2.42$ & $0.28 \mathrm{~d}$ & $4.83 \pm 0.34 \mathrm{c}$ & $3.55 \pm 0.17 \mathrm{c}$ \\
\hline $\mathbf{T}_{2}$ & $4.94 \pm 0.58$ & $4.75 \pm 0.84$ & $0.60 \pm 0.05$ & $15.36 \pm 1.29$ & $22.02 \pm 2.70$ & $18.90 \pm 1.33$ & $5.91 \pm 0.13 b$ & $5.40 \pm 0.12 a b c$ & $4.83 \pm 0.07 \mathrm{c}$ \\
\hline $\mathbf{T}_{3}$ & $5.15 \pm 0.21$ & $4.96 \pm 0.56$ & $2.88 \pm 0.19$ & $18.57 \pm 1.79$ & $24.48 \pm 3.84$ & $19.36 \pm 1.01$ & $7.36 \pm 0.22 \mathrm{a}$ & $6.46 \pm 0.27 \mathrm{ab}$ & $5.06 \pm 0.54$ \\
\hline $\mathbf{T}_{4}$ & $4.48 \pm 0.43$ & $4.38 \pm 0.80$ & $0.23 \pm 0.03$ & $14.02 \pm 2.72$ & $20.10 \pm 1.17$ & $17.41 \pm 0.85$ & $4.55 \pm 0.14 \mathrm{~cd}$ & $4.91 \pm 0.51 b c$ & $4.74 \pm 0.17 \mathrm{c}$ \\
\hline $\mathbf{T}_{5}$ & $4.98 \pm 0.59$ & $4.85 \pm 0.59$ & $0.84 \pm 0.26$ & $16.54 \pm 2.18$ & $23.39 \pm 1.01$ & $19.19 \pm 1.22$ & $6.77 \pm 0.15 c$ & $6.56 \pm 0.03 \mathrm{a}$ & $4.96 \pm 0.18 \mathrm{c}$ \\
\hline$T_{6}$ & $5.75 \pm 0.41$ & $5.14 \pm 0.46$ & $3.25 \pm 0.09$ & $20.13 \pm 1.80$ & $26.23 \pm 4.59$ & $20.79 \pm 2.71$ & $\begin{array}{c}8.92 \pm 0.38 \mathrm{c} \\
5\end{array}$ & $7.71 \pm 0.37 \mathrm{a}$ & $6.41 \pm 0.15 b$ \\
\hline $\mathbf{T}_{7}$ & $4.28 \pm 0.15$ & $2.31 \pm 0.68$ & $0.19 \pm 0.09$ & $12.05 \pm 1.78$ & $17.74 \pm 3.24$ & $14.38 \pm 1.54$ & $3.06 \pm 0.21$ & $2.86 \pm 0.23$ & $1.97 \pm 0.28$ \\
\hline
\end{tabular}

Table.10 Soil organic carbon (SOC) stocks and annual rate of change in multiple soil mass intervals (averaged over tillage crop residue practices and nutrient management rate) in 2000 and in 2018 at Meerut, U.P.

\begin{tabular}{|c|c|c|c|c|c|c|c|c|c|c|c|c|}
\hline \multirow{4}{*}{$\begin{array}{l}\text { Tillage } \\
\text { crop } \\
\text { residue } \\
\text { practices }\end{array}$} & \multicolumn{12}{|c|}{ Soil Organic Carbon ( \pm Standard error) } \\
\hline & \multicolumn{3}{|c|}{$\begin{array}{l}\text { 0-400 kg of soil m } \mathbf{~}^{-2} \\
\text { (approx. } 0-30 \mathrm{~cm} \text { ) }\end{array}$} & \multirow{2}{*}{$\begin{array}{l}\text { Annual } \\
\text { SOC } \\
\text { change } \\
\text { rate } \mathrm{g}^{-} \text {of } \\
\mathrm{Cm}^{-2} \mathrm{yr}^{-} \\
1\end{array}$} & \multicolumn{3}{|c|}{$\begin{array}{l}\text { 400-800 kg of soil m } \\
\text { (approx. } 30-60 \mathrm{~cm} \text { ) }\end{array}$} & \multirow{2}{*}{\begin{tabular}{l} 
Annual \\
\multicolumn{1}{c}{ SOC } \\
change \\
rate $\mathbf{g}$ of \\
$\mathrm{Cm}^{-2} \mathbf{y r}^{-}$ \\
1
\end{tabular}} & \multicolumn{3}{|c|}{$\begin{array}{c}800-1200 \mathrm{~kg} \text { of soil m} \mathbf{m}^{-2} \text { (approx. } \\
60-90 \mathrm{~cm})\end{array}$} & \multirow{2}{*}{$\begin{array}{l}\text { Annual } \\
\text { SOC } \\
\text { change } \\
\text { rate g of } \\
\mathrm{Cm}^{-2} \mathrm{yr}^{-} \\
1\end{array}$} \\
\hline & 2000 & 2018 & Difference & & 2000 & 2018 & Difference & & 2000 & 2018 & Difference & \\
\hline & \multicolumn{11}{|c|}{ 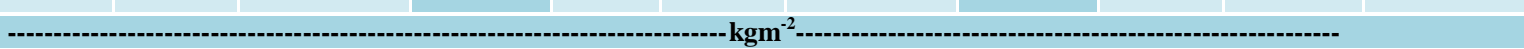 } & \\
\hline$T_{1}$ & 7.46 & $7.15^{*}$ & $-0.31 \pm 0.03$ & -28.2 & 5.39 & 5.65 & $-0.26 \pm 0.09$ & -6.9 & 3.14 & 3.12 & $-0.02 \pm 0.01$ & -1.8 \\
\hline $\mathbf{T}_{2}$ & $8.98^{*}$ & 9.77 & $0.79 \pm 0.2$ & 66.2 & 7.03 & 7.11 & $0.08 \pm 0.2$ & 1.5 & 3.72 & 3.81 & $0.09 \pm 0.11$ & 8.1 \\
\hline$T_{3}$ & $9.18^{*}$ & 9.87 & $-0.69 \pm 0.2$ & 57.4 & 7.62 & 7.64 & $0.02 \pm 0.2$ & 7.0 & 5.04 & 5.08 & $0.04 \pm 0.01$ & 1.7 \\
\hline$T_{4}$ & 8.81 & 8.75 & $-0.06 \pm 0.05$ & -25.7 & 5.82 & $5.31 *$ & $-0.51 \pm 0.2$ & -4.5 & 2.93 & 2.67 & $-0.26 \pm 0.02$ & -4.7 \\
\hline$T_{5}$ & 8.12 & $9.11 *$ & $0.99 \pm 0.2$ & 82.1 & 5.47 & 5.57 & $0.10 \pm 0.09$ & 8.8 & 3.38 & 3.47 & $0.01 \pm 0.11$ & 5.4 \\
\hline$T_{6}$ & 9.15 & 9.29 & $0.14 \pm 0.9$ & 19.6 & 5.72 & 5.88 & $0.16 \pm 0.09$ & 7.3 & 4.57 & 4.58 & $0.01 \pm 0.01$ & 0.6 \\
\hline $\mathbf{T}_{7}$ & 5.92 & 5.22 & $-0.70 \pm 0.09$ & -13.4 & 4.05 & 3.98 & $-0.07 \pm 0.09$ & -5.5 & 2.42 & 2.37 & $-0.05 \pm 0.02$ & -3.9 \\
\hline
\end{tabular}

Table.11 Soil organic carbon (SOC) stocks $(0-90 \mathrm{~cm})$, system efficiency and energy use pattern under tillage crop residue practices and nutrient management practices to the continuous RWCS

\begin{tabular}{|c|c|c|c|c|c|c|c|c|c|}
\hline \multirow{4}{*}{$\begin{array}{l}\text { Tillage } \\
\text { crop } \\
\text { residue } \\
\text { practices }\end{array}$} & \multicolumn{4}{|c|}{ Soil Organic Carbon ( \pm Standard error) } & \multirow{4}{*}{$\begin{array}{c}\text { Total } \\
\text { input } \\
\text { energy } \\
\left(\text { GJha }^{-1}\right)\end{array}$} & \multirow{4}{*}{$\begin{array}{c}\text { Specific } \\
\text { energy } \\
\left(\mathrm{MJha}^{-1}\right)\end{array}$} & \multirow{4}{*}{$\begin{array}{l}\text { Energy } \\
\text { use } \\
\text { efficiency }\end{array}$} & \multirow{4}{*}{$\begin{array}{c}\text { Net } \\
\text { energy } \\
\left(\mathbf{G J} \mathbf{h a}^{-1}\right)\end{array}$} & \multirow{4}{*}{$\begin{array}{c}\text { Total field } \\
\text { efficiency } \\
(\%)\end{array}$} \\
\hline & \multicolumn{3}{|c|}{$0-1200 \mathrm{~kg}$ of soil $\mathrm{m}^{-2}$ (approx. $0-90 \mathrm{~cm}$ ) } & \multirow{3}{*}{$\begin{array}{l}\text { Annual SOC } \\
\text { change Rate } \\
\mathrm{g} \mathrm{Cm}^{-2} \mathbf{y r}^{-1}\end{array}$} & & & & & \\
\hline & 2000 & 2018 & Difference & & & & & & \\
\hline & \multicolumn{3}{|c|}{ 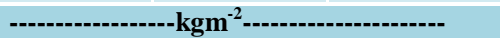 } & & & & & & \\
\hline$T_{1}$ & 16.85 & 16.35 & $-0.50 \pm 0.22$ & -45.5 & 23.8 & 4.05 & 7.08 & 46.8 & 73.25 \\
\hline $\mathbf{T}_{2}$ & 21.70 & 22.44 & $0.74 \pm 0.4$ & 61.7 & 23.1 & 3.95 & $7.12 \mathrm{~b}$ & 46.4 & 76.16 \\
\hline$T_{3}$ & 22.33 & 24.31 & $1.98 \pm 0.03 *$ & 99.2 & 21.2 & 3.91 & $7.42 \mathrm{a}$ & 42.9 & 81.44 \\
\hline $\mathbf{T}_{4}$ & 18.07 & 16.55 & $-1.52 \pm 0.4$ & -126.7 & 26.4 & 4.97 & $6.70 \mathrm{c}$ & 50.8 & 60.13 \\
\hline$T_{5}$ & 20.79 & 21.55 & $0.76 \pm 0.4$ & 63.3 & 25.7 & 4.60 & 6.90 & 50.1 & 65.06 \\
\hline$T_{6}$ & 20.89 & 21.86 & $0.97 \pm 0.2 *$ & 79.2 & 24.6 & 4.45 & $7.04 \mathrm{~b}$ & 48.3 & 66.71 \\
\hline $\mathbf{T}_{7}$ & 14.96 & 14.13 & $-0.83 \pm 0.2 *$ & -31.3 & 28.9 & 5.49 & $6.15 \mathrm{~d}$ & 61.7 & 51.98 \\
\hline
\end{tabular}

*Significant difference between years at $\alpha=0.05$

In the INM scenario i.e., NPK+FYM treatment compared to the NPK treatment, the average $\mathrm{C}$ sequestration rate was $0.17 \%$. Lal (2004) concluded that improved fertility management can enhance the SOC content at the rate of $0.05-0.15 \mathrm{Mgha}^{-1} \mathrm{yr}^{-1}$. Manna et al., (2005) observed that application of fertilizer NPK, either alone or in combination 
with FYM maintained active and slow-release pools of $\mathrm{C}$, sequestered $\mathrm{C}$ and improved soil quality and productivity. Successful integration of these emerging technologies in agro-ecosystems under rice-based production systems creates new research opportunities in South Asia.

Soil C sequestration efficiency in the CSP FYM scenario was maximum $(51.3 \%)$ in $\mathrm{T}_{3}$ ZT with 6 tha $^{-1}$ residue retained and minimum $2.1 \%$ in $\mathrm{T}_{7}$ conventional tillage practices. Such large variation could be due to differences in agronomic management parameters. An average sequestration efficiency of $12.24 \%$ was calculated across the tillage crop residue practices (Table 7). In the CSP INM scenario i.e., NPK+FYM treatment compared to the NPK treatment, the average $\mathrm{C}$ sequestration efficiency was $35.5 \%$. Kaur et al., (2008) observed that the increase in SOC in 36 years among fertilizer treatments was due to addition of carbon source through FYM, root biomass and crop residues. The exploitative practices in intensive agriculture viz. removal of plant residues, imbalanced nutrition are mainly responsible for increased carbon emissions from the soils (Lal, 2003).

\section{Soil nitrifying and denitrifying bacteria}

Table 8 shows that there were significant effects of tillage crop residue practices on the number of soil nitrifying bacteria and the number of denitrifying bacteria at the three growth stages. Compared to zero tillage with residue retention practices, the permanent raised beds with residue retention practices increased the number of soil nitrifying bacteria at the jointing and booting stages by 61.3 and $46.6 \%$ under $\mathrm{T}_{6}$, but reduced it by 37.1 and $19.8 \%$ under $\mathrm{T}_{4}$, whereas decreased it by $33.4 \%$ at the milky stage under $\mathrm{T}_{4}$ (Table 8). Similarly, the ZT and PRB with 4 and 6 tha ${ }^{-1}$ residue retention increased the number of nitrifying bacteria at the milky stage by 38.7 , 53.7 and $72.4 \%$ as compared to CT (conventional tillage), respectively. Compared to the ZT method, the PRB method reduced the number of denitrifying bacteria by 49.6 , 14.9, and $13.8 \%$ under $\mathrm{T}_{4}, \mathrm{~T}_{5}$, and $\mathrm{T}_{6}$ at the jointing stage but did not significantly decrease it at the booting stage. However, the ZT method increased the number of denitrifying bacteria at the milky stage by 9.4 , 15.7 and $19.7 \%$ under $\mathrm{T}_{4}, \mathrm{~T}_{5}$, and $\mathrm{T}_{6}$ methods (Table 8). In ZT methods, compared to CT increased the number of denitrifying bacteria at the three growth stages by $63.9,67.1$, and $70.5 \%$, respectively. In PRB method, compared to CT increased number of denitrifying bacteria at jointing and booting stages by 57.9 and $62.4 \%$, respectively.

\section{Soil enzyme activity}

Table 9 demonstrated the changes of the soil enzyme activity in different tillage crop residue practices treatments. The soil reductase, urease and invertase enzyme activities decreased in the $T_{1}, T_{4}$ and $T_{7}$ treatments, and increased in the $\mathrm{T}_{2}, \mathrm{~T}_{3}, \mathrm{~T}_{5}$ and $\mathrm{T}_{6}$. The soil enzyme activity showed that the treatments $\mathrm{T}_{5}$ and $\mathrm{T}_{6}$ comprised with the increase of continuous residue retention in rice-wheat cropping years, the differences of enzyme activity was more significant. Continuous cropping 16 years, the similarity of enzyme activities was $46.4 \%$, much more than that of $\mathrm{T}_{7}$. The other group comprised only ZT $\left(\mathrm{T}_{1}\right)$ and PRB $\left(\mathrm{T}_{4}\right)$ without residue retention, with a similarity to other groups of less than $25.4 \%$. This result indicated that the diversity of the enzyme activity was altered to a greater extent than the bacterial by continuous rice-wheat cropping system. Green et al., (2007) found that No-till management practice increase stratification of soil enzyme activities near the soil surface, perhaps due to the similar vertical distribution of SOM in NT than in CT and the activity of 
microbes. Lu et al., (2014) recently concluded that biochar and residue amendment could enhance the readily oxidized $\mathrm{C}$ (measured by $\mathrm{KMnO}_{4}$ oxidation). Jindo et al., (2012), who found the urease enzyme, determined from horizons of different soil profiles revealed decreased activities with soil depth. The differences might be attributed to decreases in soil organic matter content and numbers of microorganisms with depth. Zhang et al., (2013a) found that RDN+FYM application resulted in more nitrate in the upper $1 \mathrm{~m}$ of soil profile. Further study about residue and $\mathrm{RDN}+\mathrm{FYM}$-induced changes in soil biota (i.e., enzyme, microbial community) regarding soil $\mathrm{N}$ transformation (nitrification, denitrification) is needed, because the activity of enzymes involved in the $\mathrm{N}$ cycle could potentially be linked to $\mathrm{N}_{2} \mathrm{O}$ emissions (Harter et al., 2013).

\section{Changes in SOC over time: Temporal comparison}

When SOC was evaluated over the last 18 years, tillage crop residue practices have a significant effect at any of the analyzed soil intervals (Table 10). Quantities of SOC at the $0-400 \mathrm{~kg}$ of soil $\mathrm{m}^{-2}$ interval decreased under $\mathrm{T}_{1}, \mathrm{~T}_{4}$ and $\mathrm{T}_{7}$ treatments evaluated. Stocks of SOC in the top $400 \mathrm{~kg}$ of soil m $\mathrm{m}^{-2}$ decreased from 7.46 to $7.15 \mathrm{~kg}$ of $\mathrm{C} \mathrm{m}^{-2}$ represented a change of $-0.31 \pm 0.03 \mathrm{~kg}$ of $\mathrm{C} \mathrm{m}^{-2}$ in $\mathrm{T}_{1}, 8.81$ to $8.75 \mathrm{~kg}$ of $\mathrm{C} \mathrm{m}^{-2}$ represented a change of $0.06 \pm 0.05 \mathrm{~kg}^{\circ} \mathrm{C} \mathrm{m}^{-2}$ in $\mathrm{T}_{4}$, and 5.92 to 5.22 of $\mathrm{C} \mathrm{m}^{-2}$ represented a change of $-0.70 \pm 0.09$ $\mathrm{kg}$ of $\mathrm{C} \mathrm{m}^{-2}$ in $\mathrm{T}_{7}$ between 2000 and 2018, (Table 10). Our results clearly show that for the given conditions of this study (climatic conditions, soil type, tillage system and nutrient) zero tillage and permanent raised with 4 and 6 tha $^{-1}$ of the residue retention evaluated treatments were able to sequester atmospheric $\mathrm{C}$ or even achieve a balance between inputs and outputs. Levels of SOC were clearly lower after 16 years of cultivation under without residue retention zero tillage, permanent raised beds and conventional tillage practices and future research will be necessary to determine if and when the system achieves a balance or steady state. Soil C content in the 400-800 and 800$1200 \mathrm{~kg}$ of soil m $\mathrm{m}^{-2}$ intervals performed similar change after 18 years. Changes over the length of the study averaged over tillage crop residue practices were $-0.07 \pm 0.09$ and $0.05 \pm 0.02 \mathrm{~kg} \mathrm{C} \mathrm{m}^{-2}$ in the $400-800$ and 800 $1200 \mathrm{~kg}$ of soil $\mathrm{m}^{-2}$ intervals. This is equivalent to an average yearly change rate of -5.5 and $-3.9 \mathrm{~g} \mathrm{C} \mathrm{m}^{-2} \mathrm{yr}^{-1}$ for each mentioned soil mass interval (Table 10). Given the error associated to these estimations, SOC stock at the $400-800$ and $800-1200 \mathrm{~kg}$ of soil $\mathrm{m}^{-2}$ intervals were small and less than the precision of our ability to measure.

When SOC changes over time were considered for the whole $1200 \mathrm{~kg}$ of soil $\mathrm{m}^{-2}$, tillage crop residue practices zero tillage, permanent raised beds and conventional tillage treatments had no effect on SOC stocks (Table 11). Apparent differences observed in the 2018 samples between rotations were also present in the 2000 samples (Table 11). Under ZT, SOC changed from 16.85 to $16.35 \mathrm{~kg}$ of $\mathrm{C} \mathrm{m}^{-2}$ between 2000 and 2018, PRB 18.07 to 16.55 and under CT from 14.96 to $14.13 \mathrm{~kg}$ of $\mathrm{C} \mathrm{\textrm {m } ^ { - 2 }}$ between 2000 and 2018. Archived samples showed that the rate of SOC depletion under $\mathrm{CT}$ was 1.5 times more than that of ZT and PRB with residue retention treatments (Table 11), but this difference was statistically significant. These results emphasize the importance of having archived samples in order to determine the true effect of management practices on SOC over time (Potter, 2006). Averaged over tillage crop residue practices, stocks of SOC in $1200 \mathrm{~kg}$ of soil $\mathrm{m}^{-2}$ (approx. 0-90 $\mathrm{cm}$ ) decreased by -0.83 $\pm 0.2 \mathrm{~kg} \mathrm{~m}^{-2}$ from 14.96 to $14.13 \mathrm{~kg} \mathrm{~m}^{-2}$ between 2000 and 2016 in CT treatments but treatments ZT and PRB with residue retention 
stocks of SOC in $1200 \mathrm{~kg}$ of soil m- $\mathrm{m}^{-2}$ increased by $+1.36 \mathrm{~kg} \mathrm{~m}^{-2}$ from in $\mathrm{ZT}$ and $+0.87 \pm 0.3 \mathrm{~kg} \mathrm{~m}^{-2}$ in PRB treatments from 22.02 to 23.38 and 20.84 to 21.71 (Table 11 ). Even though the amount of SOC in the 1200 $\mathrm{kg}$ of soil m $\mathrm{m}^{-2}$ interval between 2000 and 2018 were not statistically significant, trends show that $\mathrm{C}$ is being lost from the soil rather than sequestered from the atmosphere.

These results also highlight the importance of having initial soil samples in order to accurately determine the effect of different treatments. This is especially important in deep samples $(>30 \mathrm{~cm})$ where management practices have less impact and there is a greater natural soil variability (Potter, 2006). Similarly, if we had based our conclusions on samples obtained in 2018 our results would have been somewhat different. Varvel (2008) on a study in a nearby location also pointed out the importance of more than one sampling date when assessing SOC trend over time. Although he analyzed surface samples (0-30 $\mathrm{cm}$ ), the effect of changes in management practices on SOC during the course of the experiment could have only been observed by having more than one sampling date. In our study management practices remain relatively constant during the last 18 years, thus having initial and final sampling times allowed the determination of the effects of management practices on SOC changes.

\section{The effect of tillage on the SOC}

Results in this study show that there was a redistribution of SOC in the first $400 \mathrm{~kg}$ of soil $\mathrm{m}^{-2}$ (approx. $30 \mathrm{~cm}$ ) profile under PRB as compared to ZT. While under ZT SOC stocks were greater $(+10 \%)$ in the 6 tha $^{-1}$ with residue retention $\left(\mathrm{T}_{3}\right)$ than under $\operatorname{PRB}\left(\mathrm{T}_{6}\right)$, they were slightly lower in the 4 tha $^{-1}$ with residue retention $\left(\mathrm{T}_{2}\right)$ than under PRB $\left(\mathrm{T}_{5}\right),(-$ $5.2 \%)$ and $(-3.7 \%)$, respectively (Table 10$)$. But SOC stocks under CT $\left(\mathrm{T}_{7}\right)$ were consistently lower than either under PRB or ZT (Table 10). When the $0-400 \mathrm{~kg}$ of soil $\mathrm{m}^{-2}$ under ZT and PRB with or without residue retention is considered, no significant differences in SOC stocks were observed between ZT and PRB, but $13 \%$ less SOC was observed under CT (Table 10). Soil disturbance generated by $\mathrm{CT}$ in the surface $400 \mathrm{~kg}$ of soil m $\mathrm{m}^{-2}$ could have increased the rate of SOC loss relative to $\mathrm{PRB}$ or $\mathrm{ZT}$. Conventional tillage is known to disrupt aggregates, thus reducing the physical protection (Six et al., 2004), and exposing previously inaccessible SOC to microbial degradation (Stevenson, 1994). When compared to archived soil samples, 18 years of treatment showed a decrease in SOC stocks under all of the without residue retention tillage treatments in first $400 \mathrm{~kg}$ of soil m $\mathrm{m}^{-2}$ (Table 10). The implementation of ZT or PRB without residue retention did not result in $\mathrm{C}$ sequestration but rather a decrease in the rate of SOC loss compared to CT. Although the depletion of SOC from the $0-400 \mathrm{~kg}$ of soil $\mathrm{m}^{-}$ 2 interval was not statistically different among treatments (Table 10), the rate of change was clearly greater in CT (Table 10). This suggests that 16 years were not enough to generate measurable changes in SOC between ZT, PRB and CT.

Results are in accordance with several studies (e.g. Vanden Bygaart and Angers, 2006, Baker et al., 2007) which affirm that given the great SOC background in the whole soil profile, and the small annual changes, longterm studies are vital in order to determine differences in the effect of management practices. In the soil layer immediately below the plow layer (400-800 $\mathrm{kg} \mathrm{m}^{-2}$ ), when SOC stocks were evaluated over time it was evident that in the period between soil samplings (2000-2018), the SOC stocks had decreased considerably under CT while remaining practically unchanged under ZT or PRB (Table 10). There was no difference 
between SOC stocks in 2000 and 2018 under ZTT and PRB (Table 10). The annual rate of SOC loss in the $400-800 \mathrm{~kg}$ of soil $\mathrm{m}^{-2}$ interval under CT was $-5.5 \mathrm{~g} \mathrm{C} \mathrm{m}^{-2} \mathrm{yr}^{-1}$ while under ZT and DK the rate of SOC change was $+7.0 \mathrm{~g} \mathrm{C} \mathrm{m}^{-2} \mathrm{yr}^{-1}$ and $+7.3 \mathrm{~g} \mathrm{C} \mathrm{m}^{-2} \mathrm{yr}^{-1}$, respectively (Table 10). Given the error associated to the estimations, SOC stocks under ZT and PRB were considered unaffected my tillage at this soil mass interval. Therefore, the increased soil disturbance with CT could have produced a sudden increase in soil aeration (as well as changes in soil temperature and moisture) at greater depths compared to ZT or less invasive tillage as PRB. Exposing SOM at depth to more oxidative environments would speed decomposition (Halvorson et al., $2002 \mathrm{~b}$ ), and could be the cause of SOC depletion at the $400-800 \mathrm{~kg}$ of soil $\mathrm{m}^{-2}$ interval under CT. As expected, in the 800$1200 \mathrm{~kg}$ of soil m $\mathrm{m}^{-2}$ interval (approx. 60-90 $\mathrm{cm}$ ), SOC was unaffected by management practices and remained invariable under all of the evaluated treatments (Table 10).

Finally, when considering soil $\mathrm{C}$ changes in the whole $1200 \mathrm{~kg}$ of soil $\mathrm{m}^{-2}$ (approx. $90 \mathrm{~cm}$ depth) there were differences among tillage treatments in 2000 but were wider to becoming significant in 2018. Soil C stocks increased by $0.74,0.76,0.97$ and $1.98 \mathrm{~kg} \mathrm{C}$ $\mathrm{m}^{-2}$ under $\mathrm{T}_{2}, \mathrm{~T}_{5}, \mathrm{~T}_{6}$ and $\mathrm{T}_{3}$ treatments over the last 18 years of the experiment (Table 11). Assuming a constant rate of change of the SOC stocks over the last 18 years, CT doubled the rate of SOC change under ZT or PRB being 61.2, 63.3, 79.2 and $99.2 \mathrm{~g} \mathrm{C} \mathrm{m}^{-2}$ $\mathrm{yr}^{-1}$ (Table 11). Despite these observed differences between treatments, when $\mathrm{C}$ changes for each treatment were analyzed over time, the differences were statistically significant (Table 10 and 11).Greater SOC stocks under ZT and PRB as compared to CT were observed in the surface $400 \mathrm{~kg}$ of soil $\mathrm{m}^{-2}$ after 18 years. Temporal comparisons using archive samples showed that although not declared significant, more SOC was being lost under CT than under either ZT or PRB without residue retention. This suggest that probably more than 18 years are required, given the conditions of this experiment, to detect differences among the evaluated tillage systems in the surface $400 \mathrm{~kg}$ of soil m $\mathrm{m}^{-2}$ (approx. $30 \mathrm{~cm}$ ). In the $400-800 \mathrm{~kg}$ of soil $\mathrm{m}^{-}$ ${ }^{2}$, SOC stocks were observed to decrease under CT after only 18 years while remaining invariable under ZT and PRB. Tillage did not impact SOC stocks in the $800-1200 \mathrm{~kg}$ of soil $\mathrm{m}^{-2}$ interval. Having archived soil samples allowed the determination of the true rate of change. By comparing current soil samples to archived soil samples it was possible to determine that although more carbon was found for ZT and PRB with residue retention than for CT, all of the residue removed tillage treatments had lost SOC over time.

\section{Energy dynamics and energy use efficiencies}

Keeping in view current energy crisis, studies on energy dynamics and energy use efficiency in agricultural production systems also assume great importance to identify promising production systems which have less dependency on non-renewable energy sources. In the current study, the estimation of energy use in different tillage crop residue practices revealed that $\mathrm{T}_{7}$ (conventional tillage) utilized highest energy (28.9 $\mathrm{GJ}^{-1} \mathrm{ha}^{-1}$ ) followed by $\mathrm{T}_{4} \mathrm{PRB}$ without residue retention (26.4 GJ ha $\left.{ }^{-1}\right), T_{5}$ PRB with 4 tha $^{-1}$ residue retained and $T_{6}$ PRB with 6 tha $^{-1}$ residue retained, respectively. $\mathrm{T}_{7}$ (conventional tillage) practices used highest energy input because rice consumes higher energy with respect to puddling, nursery raising as well as human labour for transplanting and thrashing operations in rice; besides more energy input in tillage operations in wheat. $\mathrm{T}_{4}$ permanent raised beds without residue retention also consumed more energy owing to regular spraying of weedicides in rice crop being 
prone to weed infestation besides relatively frequent irrigation requirements in rice and wheat (Kumar et al., 2013; Naresh et al., 2015). $\mathrm{T}_{1} \mathrm{ZT}$ without residue retained and $\mathrm{T}_{2}$ ZT with 4 tha $^{-1}$ residue retained tillage practices also produced higher energy equivalents which resulted in greater net energy returns quite close to $\mathrm{T}_{3} \mathrm{ZT}$ with 6 tha ${ }^{1}$ residue retained practice was primarily due to higher yield of this system. The energy use efficiency was highest in $\mathrm{T}_{3}$ (7.42) followed by $\mathrm{T}_{2}$ (7.12), $\mathrm{T}_{1}$ (7.08), $\mathrm{T}_{6}(7.04)$ and least in $\mathrm{T}_{7}$ (6.15). Due to lesser energy input and higher output $\mathrm{T}_{3}$ had $20 \%$ and $5 \%$ higher energy use efficiency than $\mathrm{T}_{7}$ and $\mathrm{T}_{6}$ (Table 11). Based upon the energy output and energy input use under different tillage methods in rice-wheat cropping system, $\mathrm{T}_{3}$ had energy gains of $8 \%, 7 \%, 4 \%$ and $2 \%$ than $\mathrm{T}_{7}, \mathrm{~T}_{4}, \mathrm{~T}_{5}$ and $\mathrm{T}_{6}$, respectively (Table 11 ).

Carbon and nitrogen dynamics in soils are complex phenomenon, which vary depending on soil and crop management practices and may have profound effects on global warming and climate change.

Farm yard manure was found efficient to increase carbon and nitrogen in soils compared to rice-wheat straw, which decreased with increased soil depths irrespective of residues. Positive trend of carbon enrichment in soils was found while, FYM and rice-wheat straw were applied, which could be monitored and maintained through regular replenishment of organic materials in soils. Any type of soil and crop management practices that could enhance carbon contents in soils should be considered and recommended for farmers' practice. Use of crop residues, animal manures, minimum or zero tillage, balanced fertilization may replenish and increase carbon stock in soils and bring multitude of benefits for agricultural sustainability.
The current study showed that the NPK+FYM treatment have good potential in $\mathrm{C}$ sequestration in Indian soils without any additional cost. Increasing SOC in soil makes soil more productive leading to increased crop yield. Thus FYM application was a 'win-win' technology increasing farm income and also sequestering $\mathrm{C}$. In view of the decreasing availability of FYM, however, application of $10.7 \mathrm{Mg} \mathrm{ha}^{-1}$ of FYM (equivalent to $60 \mathrm{~kg} \mathrm{~N}$ ) on dry weight basis is difficult. Treatment involving 50 per cent recommended dose of $\mathrm{N}$ supplied through chemical fertilizers and another 50 per cent through FYM reduced the depletion of SOC stocks and produced higher yields. Increase in SOC stock by $1 \mathrm{Mg} \mathrm{ha}^{-1}$ in $1-\mathrm{m}$ depth increased cumulative grain yield by $0.46 \mathrm{Mg} \mathrm{ha}^{-1}$. However, most $\geq(7$ per cent) of the $\mathrm{C}$ supplemented through FYM in this climate was mineralized and only a small fraction $\geq(23$ per cent) was stabilized into SOC stock. The rate of addition of organic amendments should be at least doubled to reduce SOC depletion and increased considerably to enhance the SOC stock. Increased SOC stock in the surface $50 \mathrm{~kg} \mathrm{~m}^{-2}$ under $\mathrm{ZT}$ and $\mathrm{PRB}$ was compensated by greater SOC stocks in the 50-200 and 200-400 $\mathrm{kg} \mathrm{m}^{-2}$ interval under residue retained, but SOC stocks under CT were consistently lower in the surface $400 \mathrm{~kg} \mathrm{~m}^{-2}$. Over the last 18 years, CT lost $0.83 \pm 0.2 \mathrm{~kg}$ of $\mathrm{C} \mathrm{m}^{-2}$ while ZT gain $1.98 \pm 0.3$ and $P R B$ gain $0.97 \pm 0.2 \mathrm{~kg}$ of $\mathrm{C} \mathrm{m}^{-2}$ in the $1200 \mathrm{~kg}$ of soil $\mathrm{m}^{-2}$ profile. Thus, conjunctive use of $50 \% \mathrm{FYM}+50 \% \mathrm{RDF}$ is viable option for curbing SOC depletion and sustaining crop production. The technologies of SOC sequestration, therefore, need to be promoted by providing incentives, technological know-how, required resources and policy support to the farmers.

\section{Acknowledgements}

This work was supported by Uttar Pradesh Council of Agricultural Research, Lucknow 
on "Resource Conservation Technologies for Sustainable Development of Agriculture- is gratefully acknowledged by the authors. We are grateful to the authorities of the Sardar Vallabbhai Patel University of Agriculture \& Technology, Meerut, U.P., India for all support in execution of this experiment. We also acknowledge the technical support from. Moreover, we would like to express our great respect for the editors and anonymous reviewers to improve the manuscript quality.

\section{References}

Baker, J.M., T.E. Ochsner, R.T. Ventura and T.J. Griffis, 2007. Tillage and soil carbon sequestration-What do we really know? Agric. Ecosyst. Environ. 118:15.

Bhatia A., Aggarwal P. K., Jain N. and Pathak H. 2011. Greenhouse gas emission from rice-wheat growing areas in India: spatial analysis and upscaling. $G H G S c i$ Techn, 2: 115-125.

Bhattacharyya R, Tuti M D, Bisht J K, Bhatt J C, Gupta H S. 2012a. Conservation tillage and fertilization impact on soil aggregation and carbon pools in the Indian Himalayas under an irrigated rice-wheat rotation. Soil Sci 177: 218228.

Bhattacharyya, R., Prakash, V., Kundu, S., Srivastava, A.K. and Gupta, H.S. 2009b. Soil properties and their relationships with crop productivity after 30 years of different fertilization in the Indian Himalayas. Archieves Agro. Soil Sci. 55: 641-661.

Bouyoucos, G.J. 1962. Hydrometer method improved for making particle size analysis of soils. Agron. J. 54:464-465.

Chivenge, P.P., H.K. Murwira, K.E. Giller, P. Mapfumo, and J. Six. 2007. Long-term impact of reduced tillage and residue management on soil carbon stabilization: Implications for conservation agriculture on contrasting soils. Soil Tillage Res. 94:328-337

Duval, M.E., Galantini, J.A., Iglesias, J.O., Canelo, S., Martinez, J.M., Wall, L. 2013. Analysis of organic fractions as indicators of soil quality under natural and cultivated systems. Soil Tillage Res. 131: 11-19.

Franzluebbers A.J. and Arshad M.A. 1997. Soil microbial biomass and mineralizable carbon of water-stable aggregates. Soil Sci Soc Am J 67: 10901097

Ghimire R, Adhikari K R, Chen Z S, Shah S C, Dahal K R. 2012. Soil organic carbon sequestration as affected by tillage, crop residue, and nitrogen application in rice-wheat rotation system. Paddy Water Environ. 10: 95102.

Ghimire R, Machad, S, Rhinhart K. 2015. Long-term crop residue and nitrogen management effects on soil profile carbon and nitrogen in wheat-fallow systems. Agron J 107: 2230-2240.

Green, V.S., Stott, D.E., Cruz, J.C., Curi, N., 2007. Tillage impacts on soil biological activity and aggregation in Brazilian Cerrado Oxisol. Soil Tillage Res. 92:114-121.

Guan, S.Y. 1986. Soil Enzyme and Study Methods of Soil Enzyme. Beijing: Agriculture Publication House

Halvorson A.D., Wienhold B.J. and Black A.L. 2002b. Tillage, nitrogen, and cropping system effects on soil carbon sequestration. Soil Sci Soc Am J 66: 906-912

Hanway, J.J. and Heidel, H. 1952. Soil analysis methods as used in Iowa state college soil testing laboratory. Iowa Agric. 27:1-13.

Hao, X.H., Liu, S.L., Wu, J.S., Hu, R.G., Tong, C.L., Su, Y.Y. 2008. Effect of long-term application of inorganic fertilizer and organic amendments on 
soil organic matter and microbial biomass in three subtropical paddy soils. Nutr. Cycl. Agroecosyst. 81: 1724.

Harter, J.; H.M. Krause, S. Schuettler, R. Ruser, M. Fromme, T. Scholten, Kappler A. and Behrens, S. 2014. Linking $\mathrm{N}_{2} \mathrm{O}$ emissions from biocharamended soil to the structure and function of the $\mathrm{N}$-cycling microbial community. ISME J. 8:660-674.

Haynes, R.J., 2005. Labile organic matter fractions as central components of the quality of agricultural soils: an overview. Adv. Agron. 85: 221-268.

Horwath, W.R. and Paul, E.A. 1994. Microbial Biomass," In: R. W. Weaver, et al., Eds., Methods of Soil AnalysisPart 2, Microbiological and Biochemical Properties, $2^{\text {nd }}$ Edition, Soil Science Society of America, Madison, 1994, pp. 753-771.

Jackson, M.L. I973. Soil Chemical Analysis, Prentice Hall of India Pvt. Ltd., New Delhi.

Jindo K., K. Suto, K.Matsumoto, C. García, T. Sonoki, and M. A. SanchezMonedero. 2012. Chemical and biochemical characterisation of biocharblended composts prepared from poultry manure. Bioresour. Technol. 110:396-404.

Kaur, T.; Brar, B.S. and Dhillon, N.2008. Soil organic matter dynamics as affected by long-term use of organic and inorganic fertilizers under maize-wheat cropping system. Nutr. Cycl. Agroecosys. 81: 5969.

Kumar Vivak, Saharawat, Yashpal S., Gathala, Mahesh K., Jat Arjun Singh, Singh, Sanjay K., Chaudhary Neelam and Jat M. L.2013.Effect of different tillage and seeding methods on energy use efficiency and productivity of wheat in the Indo-Gangetic Plains. Field Crops Res 142: 1-8
Lal R, Follett F, Stewart B A, Kimble J M. 2007. Soil carbon sequestration to mitigate climate change and advance food security. Soil Sci 172: 943-956.

Lal R., Kimble J.M. and Stewart BA.1995. World soils as a source or sink for radioactively-active gases. In: Lal $\mathrm{R}$, editor, Soil management and greenhouse effect. Adv soil sci.CRC Press, Boca Raton, FL, pp1-8

Lal, R. 2004. Soil carbon sequestration in India. Climatic Change 65: 277-296

Lal, R., J.M. Kimble, R.F. Follet, and V. Cole. 1998. Potential of U.S. cropland for carbon sequestration and greenhouse effect mitigation. UDSANRCS, Washington, DC and Ann Arbor Press, Chelsea, MI

Lorenz, K. and Lal, R. 2005. The depth distribution of soil organic carbon in relation to land use and management and the potential of carbon sequestration in subsoil horizons. $A d v$ Agro.88:35-66.

Lu N., X. Liu, Z. Du, Y. Wang, and Q. Zhang. 2014. The effect of biochar on soil respiration in the maize growing season after 5 years of consecutive application. Soil Res. 52: 505-512.

Majumder, B., Mandal, B., Bandyopadhyay, P.K., Gangopadhyay, A., Mani, P.K., Kundu, A.L. and Majumder, D. 2008. Organic amendments influence soil organic carbon pools and crop productivity in a 19 years old rice-wheat agro-ecosystem. Soil Sci. Soc. Am. J. 72: 775-785.

Malhi, S.S. and Gill, K.S. 2002. Fertilizer N and $\mathrm{P}$ effects on root mass of brome grass, alfalfa and barley. J Sustain Agr 19:51-63

Mandal, A., Patra, A.K., Singh, D., Swarup, A., Masto, R.E. 2007. Effect of longterm application of manure and fertilizer on biological and biochemical activities in soil during crop 
development stages. Bioresour. Technol. 98: 3585-3592.

Manna M C, Swarup A, Wanjari R H, Ravankar H N, Mishra B, Saha M N, Singh Y V, Sahi D K, Sarap P A. 2005. Long-term effect of fertilizer and manure application on soil organic carbon storage, soil quality and yield sustainability under sub-humid and semi-arid tropical India. Field Crops Res. 93: 264-280

Naresh R.K.; Gupta Raj K.;Gajendra Pal; Dhaliwal S.S.; Kumar Dipender; Kumar Vineet; Arya Vichitra Kumar; Raju; Singh S.P. ;Basharullah; Singh Onkar and Kumar Pardeep. 2015. Tillage Crop Establishment Strategies and Soil Fertility Management: Resource Use Efficiencies and Soil Carbon Sequestration in a Rice-Wheat Cropping System. Eco. Env. \& Cons. 21: 121128.

Nyborg, M.; Malhi, S.S.; Solberg, E.D. and Izaurralde, R.C.1999.Carbon storage and light fraction $\mathrm{C}$ in a grassland Dark Gray Chernozem soil as influenced by $\mathrm{N}$ and $\mathrm{S}$ fertilization. Can J Soil Sci 79:317-320

Olsen, S.; Cole, C.; Watanabe, F. and Dean, L. 1954. Estimation of available phosphorus in soils by extraction with sodium bicarbonate. USDA Circular $\mathrm{Nr}$ 939, US Gov. Print, Washington, D.C

Pandey D, Agrawal M, Singh Bohra J, Adhya T K, Bhattacharyya P. 2014. Recalcitrant and labile carbon pools in a sub-humid tropical soil under different tillage combinations: A case study of rice-wheat system. Soil Tillage Res 143: 116-122.

Paustian K., Robertson G.P. and Elliott E.T.1995. Management impacts on carbon storage and gas fluxes in midlatitudes cropland. In: Lal $\mathrm{R}$, editor, Soils and global climate change. Adv soil sci.CRC Press, Boca Raton, FL, USA, pp. 69-83.

Paustian, K., Parton, W.J., Persson, J. 1992. Modeling soil organic matter in organic amended and nitrogen fertilizer longterm plots. Soil Sci. Soc. Am. J. 56: 476-488.

Potter, K. N. 2006. Soil carbon content after 55 years of management of a Vertisol in central Texas. J. Soil Water Conserve. 61: 358-363.

Rahman M. M. 2013. Nutrient use and carbon sequestration efficiencies in soils from different organic wastes in rice and tomato cultivation. Communications Soil Sci Plant Ana, 44 (09): 1457-1471.

Sainju U.M., Caesar-TonThat T., Lenssen A.W., Evans R.G. and Kolberg R. 2007.Long-term tillage and cropping sequence effects on dryland residue and soil carbon fractions. Soil Sci Soc Am J 71: $1730-1739$

Sainju U.M., Lenssen A.W., Caesar-Tonthat T. and Waddell J.2006b. Tillage and crop rotation effects on dryland soil and residue carbon and nitrogen. Soil Sci Soc Am J 70: 668-678

Salvo, L., Hernández, J., Ernst, O. 2010. Distribution of soil organic carbon in different size fractions, under pasture and crop rotations with conventional tillage and no-till systems. Soil Tillage Res. 109: 116-122.

Sherrod LA, Peterson GA, Westfall DG, Ahuja LR (2003) Cropping intensity enhances soil organic carbon and nitrogen in a no-till agro-ecosystem. Soil Sci Soc Am J 67: 1533-1543

Singh, B., and S.S. Malhi. 2006. Response of soil physical properties to tillage and residue management on two soils in a cool temperate environment. Soil Tillage Res. 85:143-153

Singh, R.P., Das, S.K., Bhaskara Rao, U.M., M. Reddy and Narayana, M. 1990. Sustainability index under different 
management. Annual Report.Central Research Inst. for Dryland Agric. Hyderabad, India.

Six J., Elliott E.T. and Paustian K.1999. Aggregate and soil organic matter dynamics under conventional and notillage systems. Soil Sci Soc Am J 63: $1350-1358$

Six, J., H. Bossuyt, S. Degryze, and K. Denef. 2004. A history of research on the link between (micro) aggregates, soil biota, and soil organic matter dynamics. Soil Tillage Res. 79:7-31.

Snyder, J.D. and Trofymow, J.A. 1984. A rapid accurate wet oxidation diffusion procedure for determining organic and inorganic carbon in pot and soil samples. Communications in Soil Sci. Plant Analysis. 15: 587-597.

Soderstorm B. O., Hedlund K., Jackson L. E., Kattere T., Lugato E., Thomsen I. K. and Jorgensen H.B. 2014. What are the effects of agricultural management on soil organic carbon (SOC) stock? Environmental Evidence, 3:1-8.

Soon Y K and Arshad M A. 2005. Tillage and liming effects on crop and labile soil nitrogen in an acid soil. Soil Tillage Res. 80:23-33.

Subbiah, B.V. and Asija, G.L. 1956. A rapid procedure for determination of available nitrogen in soil. Curr. Sci. 25: 256-260.

VandenBygaart, A.J., and D.A. Angers. 2006. towards accurate measurements of soil organic carbon stock change in agroecosystems. Can. J. Soil Sci. 86: 465471.
Varvel, G.E., and W.W. Wilhelm. 2008. Soil carbon levels in irrigated western Corn Belt rotations. Agron. J. 100: 11801184.

Veihmeyer, F.J. and Hendrickson A.H. 1948. Soil density and root penetration. Soil Sci. 65: 487-493.

Verhulst, N., Govaerts, B., Verachtert, E., Castellanos-Navarrete, A., Mezzalama, M., Wall, P., Decker, J., Sayre, K.D. 2010. Conservation agriculture, improving soil quality for sustainable production systems? In: Lal, R., Stewart, B.A. (Eds.), Advances in Soil Science: Food Security and Soil Quality. CRC Press, Boca Raton, FL, USA, pp. 137-208

Walkley, A.J. and Black,.IA. 1934. An estimation of the Degtjareft method for determining of soil organic matter and a proposed modification of chromic acid titration method. Soil Sci., 37: 29-38.

Williams, C.H. and Steinbergs, A. 1959. Soil sulphur fractions as chemical indices of available sulphur in some Australian soils. Australian J Agri Res 10: 342352.

Xue, J., Pua, C., Liua, S., Chena, Z., Chena, F., Xiaob, X., Lalc, R., Zhanga, H. 2015. Effects of tillage systems on soil organic carbon and total nitrogen in a double paddy cropping system in Southern China. Soil Tillage Res. 153: 161-168.

Zhang Q., X. Wang, Z. Du, X. Liu, and Y. Wang. 2013a. Impact of biochar on nitrate accumulation in an alkaline soil. Soil Res. 51: 521-528.

\section{How to cite this article:}

Naresh, R.K., R.K. Gupta, Vivek, R.S. Rathore, S.P. Singh, Ashok Kumar, Sunil Kumar, D.K. Sachan, S.S. Tomar, N.C. Mahajan, Lali Jat and Mayank Chaudhary. 2018. Carbon, Nitrogen Dynamics and Soil Organic Carbon Retention Potential after 18 Years by Different Land Uses and Nitrogen Management in RWCS under Typic Ustochrept Soil. Int.J.Curr.Microbiol.App.Sci. 7(12): 3376-3399. doi: https://doi.org/10.20546/ijcmas.2018.712.388 